\title{
DIFFERENTIATION OF THE FOSSIL HEXAPODIDAE MIERS, 1886 (DECAPODA: BRACHYURA) FROM SIMILAR FORMS
}

\author{
CARRIE E. SCHWEITZER AND RODNEY M. FELDMANN \\ Department of Geology, Kent State University, Kent, Ohio, $44242<$ cschweitzer@stark.kent.edu>, <rfeldman@geology.kent.edu>
}

\begin{abstract}
Distinguishing among members of the Hexapodidae Miers, 1886, the Asthenognathinae Stimpson, 1858, and the Chasmocarcininae Serène, 1964, is difficult in fossil specimens that lack preserved pereiopods or sterna. Members of the Hexapodidae are easily identified if sterna and pereiopods are present, because possession of four pairs of pereiopods and seven exposed sternites is diagnostic for the family. Several features of the dorsal carapace are useful in differentiating among genera assigned to that family and other subfamilies belonging to the Goneplacidae and Pinnotheridae; however, dorsal carapace characters are less useful in assigning taxa at the family or subfamily level. A key to the taxa discussed herein permits generic differentiation based upon the relative dimensions of the carapace, the shape and size of the orbits, the shape and size of the rostrum, carapace ornamentation, and the degree of fusion of abdominal somites in males.

A new species of Palaeopinnixa Via, 1966, Palaeopinnixa rotundus, is described from the Eocene Coaledo Formation of Oregon, USA. A new hexapodid genus and species, Globihexapus paxillus, is recognized from the Miocene Astoria Formation of Washington, USA. Prepaeduma decapoda Morris and Collins, 1991, is referred to Hexapus de Haan, 1833. Viapinnixa new genus has been erected to accommodate material previously assigned to Pinnixa (Palaeopinnixa) nodosa Collins and Rasmussen, 1992, and Orthakrolophos has been named to accommodate three species of Palaeograpsus Bittner, 1875. Asthenognathus urretae new species is described from the middle Eocene Centinela Formation of southern Argentina.
\end{abstract}

\section{INTRODUCTION}

$\mathrm{T}^{\mathrm{H}}$ HE HEXAPODIDAE is easily distinguished from all other brachyuran families by possession of four pairs of pereiopods instead of five and seven exposed sternites instead of eight. However, it is difficult to distinguish among species of the Hexapodidae, the pinnotherid subfamily Asthenognathinae and the goneplacid subfamily Chasmocarcininae in fossils that lack preserved pereiopods or sterna. Each group is characterized by possession of small, rectangular to ovate, indistinctly ornamented carapaces that are difficult to distinguish from one another. The problem is especially acute when working with fossil material that is limited to dorsal carapace material, because familial and generic assignment of extant taxa in these groups is commonly based upon characters that do not readily fossilize, such as aspects of the antennae, antennules, eyes, maxillipeds, and pleopods.

It is the purpose of this paper to provide some commonly preserved dorsal carapace characters that are useful in distinguishing among the Hexapodidae, Asthenognathinae, and Chasmocarcininae in fossil specimens (Table 1). Generic-level distinctions can be made with relative ease based upon dorsal carapace characters; a key to all known hexapodid and selected asthenognathine and chasmocarcinine genera utilizes these characters to distinguish genera (Appendix A). The pinnotherid subfamilies Xenophthalminae, Pinnotherellinae, and Pinnotherinae and many genera of the Asthenognathinae and the Chasmocarcininae are excluded from the key because they are easily distinguished from the Hexapodidae, as is discussed below.

Although generic level distinctions are possible, it is somewhat more difficult to differentiate the Hexapodidae, the Asthenognathinae, and the Chasmocarcininae in the fossil record at the family or subfamily level based upon dorsal carapace features. Family and subfamily level placement is much simplified once the fossils have been assigned to a genus. This approach represents a union of biological and paleontological criteria. The Hexapodidae, Asthenognathinae, and Chasmocarcininae are defined in biological terms by criteria almost entirely unavailable to paleontologists, and in fact, differentiation of those higher level taxa would be very difficult based upon fossil material alone. However, use of carapace features available to paleontologists permits assignment of taxa to genera and consequently to higher level taxa. This approach has made it possible to use these taxa, which previously were relatively uninformative because of questionable higher taxonomic placement, for more broad-based paleontological studies in such realms as paleoecology, paleobiogeography, and phylogeny.

With the above caveats in mind, it is possible to generalize about the dorsal carapace and ventral morphology of each family or subfamily; however, there are instances in which family-level placement must be considered tentative. Because determination of the evolutionary and biogeographic histories of these groups is dependent upon accurate generic identification and family placement, some taxa remain of little utility for broad-based paleontological studies.

The similarities in dorsal carapace morphology within these families and subfamilies are probably a result of convergence, perhaps because most pinnotherids and hexapodids are commensal within other organisms. The small, generally smooth carapace probably facilitates movement into and out of the host organism. Species of Chasmocarcinus are an exception; they are free-living (Rathbun, 1918b).

The Asthenognathinae has a limited fossil record; only Asthenognathus has been recorded as fossil species. By contrast, the Hexapodidae and the Chasmocarcininae have comparatively robust fossil records ranging in age from Paleocene to Recent and from localities worldwide.

A second purpose of this paper is to describe several new taxa and combinations. The new hexapodids Palaeopinnixa rotundus n. sp. and Globihexapus paxillus n. gen. and sp. were collected from the Eocene Coaledo Formation of Oregon and the Miocene Astoria Formation of southwestern Washington respectively. Prepaeduma decapoda Morris and Collins, 1991, is referred to Hexapus de Haan, 1833. Falconoplax Van Straelen, 1933, Collinsius Karasawa, 1993, and Orthakrolophos n. gen. are all referred to the Chasmocarcininae, and three species of Palaeograpsus Bittner, 1875 are referred to Orthakrolophos n. gen. Viapinnixa n. gen. is erected to accommodate Pinnixa (Palaeopinnixa) nodosa Collins and Rasmussen, 1992, from the Danian of Greenland and is referred to the Pinnotheridae sensu lato. A new species of the Asthenognathinae, Asthenognathus urretae, is described from the Eocene Centinela Formation, near Calafate, Argentina. 
TABLE 1 -Characters useful in differentiating the three higher level taxa discussed here. *There are two exceptions, Spiroplax and Globihexapus, with ratios of 0.61 and 0.59 respectively. FOW/PW $=$ fronto-orbital width/posterior width; $\mathrm{PW} / \mathrm{W}=$ posterior width/maximum carapace width.

\begin{tabular}{|c|c|c|c|}
\hline Characters & Hexapodidae & Asthenognathinae & Chasmocarcininae \\
\hline Carapace shape & Rectangular & Trapezoidal & Trapezoidal \\
\hline Pairs of pereiopods & 4 pairs & 5 pairs & 5 pairs \\
\hline Number of sterna & 7 & 8 & 8 \\
\hline Front & $\begin{array}{l}\text { Widest distally, bilobed, usually ex- } \\
\text { tending well beyond orbits }\end{array}$ & $\begin{array}{l}\text { Short, down-turned, narrowest } \\
\text { distally }\end{array}$ & $\begin{array}{l}\text { Bilobed, extending beyond } \\
\text { orbits }\end{array}$ \\
\hline Lateral ridge & Sometimes present & Absent & Absent \\
\hline Fronto-orbital width & $\begin{array}{l}\text { Partially occupies straight frontal } \\
\text { margin }\end{array}$ & $\begin{array}{l}\text { Occupies entire straight fron- } \\
\text { tal margin }\end{array}$ & $\begin{array}{l}\text { Occupies entire or nearly en } \\
\text { tire straight frontal margin }\end{array}$ \\
\hline PW/W Ratio & $0.73-0.93 *$ & $0.64-0.66$ & $0.41-0.56$ \\
\hline FOW/PW Ratio & $0.34-0.87$ & $0.70-1.00$ & $0.77-1.20$ \\
\hline $\begin{array}{l}\text { Fusion of abdominal somites in } \\
\text { males }\end{array}$ & $\begin{array}{l}\text { Fusion always present, usually so- } \\
\text { mites } 3-5\end{array}$ & Somites $4-6$ usually fused & Somites $3-5$ fused \\
\hline $\begin{array}{l}\text { Point of maximum width of dorsal } \\
\text { carapace }\end{array}$ & $\begin{array}{l}\text { Just anterior to posterolateral reen- } \\
\text { trants }\end{array}$ & $\begin{array}{l}\text { Just anterior to posterolateral } \\
\text { reentrants }\end{array}$ & $\begin{array}{l}\text { Just anterior to posterolateral } \\
\text { reentrants }\end{array}$ \\
\hline Posterolateral reentrants & Moderately to well-developed & Well-developed, large & Well-developed \\
\hline
\end{tabular}

SYSTEMATIC PALEONTOLOGY

Order DECAPODA Latreille, 1803

Infraorder BRACHYURA Latreille, 1803

Section HeTEROTREMATA Guinot, 1977

Superfamily XANTHOIDEA Macleay, 1838

Family HeXAPODIDAE Miers, 1886

Diagnosis. - Carapace rectangular, or rarely, trapezoidal; wider than long, average L/W about 0.68 with range of $0.57-0.83$; lateral margins steep; regions typically poorly or moderately well defined. Front typically widest distally, axially sulcate, usually extending at least weakly beyond orbits, not deflexed. Orbits usually rimmed, upper margin sinuous; straight frontal margin only partially occupied by orbits, except in Goniocypoda and Globihexapus; fronto-orbital width to width ratio averaging about 0.45 , range of $0.32-0.64$; fronto-orbital width to posterior width ratio averaging about 0.63 , range of $0.34-0.86$. Anterolateral and posterolateral margins indistinguishable, often with rim or ridge parallel to lateral margin; posterolateral reentrant moderately well developed; posterior margin sometimes with small reentrant axial to posterolateral corner; posterior width to maximum width ratio ranging from 0.73-0.93, except in Globihexapus (0.59) and Spiroplax $(0.61)$. Regions usually poorly defined. Sternite 4 with anterior projections. Sternite 8 obscured and pereiopods 5 missing. Male abdominal somites exhibiting fusion, usually somites 3-5.

Included genera.-Globihexapus new genus; Goniocypoda Woodward, 1867; Hexapinus Manning and Holthuis, 1981; Hexaplax Doflein, 1904; Hexapus de Haan, 1833; Lambdophallus Alcock, 1900; Paeduma Rathbun, 1897; Palaeopinnixa Via, 1966; Parahexapus Balss, 1922; Pseudohexapus Monod, 1956; Spiroplax Manning and Holthuis, 1981; Stevea Manning and Holthuis, 1981; Thaumastoplax Miers, 1881; Tritoplax Manning and Holthuis, 1981.

Discussion.-Several generalizations can be made that assist in distinguishing among the Hexapodidae, the pinnotherid subfamilies, and the Chasmocarcininae. The Hexapodidae is distinguished from all other brachyuran families based upon possession of only four pairs of pereiopods and a much reduced eighth sternite, which is hidden by the abdomen and the posterior margin of the carapace (Gordon, 1971; Manning and Holthuis, 1981). There is no definitive set of dorsal carapace characters that can be used to distinguish hexapodids from asthenognathines or chasmocarcinines at the family or subfamily level. However, genera can be distinguished from one another by using the characters employed in the key (Appendix A) and in Table 2, and then assigned to the appropriate family and/or subfamily.
Pinnotherids exclusive of the Asthenognathinae are easily distinguished from members of the Hexapodidae. The Asthenognathinae will be discussed in greater detail below. The rostrum is generally poorly developed in the Pinnotheridae. Members of the Pinnotherinae de Haan and Pinotherellinae Alcock of the Pinnotheridae typically do not possess well-developed orbits as do the hexapodids. The Xenophthalminae Alcock have well-developed orbits, but have distinctive longitudinal reentrants on the upper margin of the orbits that clearly distinguish them from the Hexapodidae.

Several aspects of the shape of the dorsal carapace may be used to distinguish between hexapodids and members of the Pinnotheridae exclusive of the Asthenognathinae. Members of the Pinnotherellinae possess a rounded or ovate carapace, unlike hexapodids. Those pinnotherids that do possess a transversely elongate dorsal carapace typically are not rectangular in shape as are most hexapodids; instead, they tend to be hexagonal or ovate in shape. In members of the Pinnotheridae, the posterior margin is usually narrow. Finally, members of the Pinnotheridae typically do not have ridges on the dorsal carapace parallel to the lateral margins as do some hexapodids.

Some features of the sternum and abdomen can be used to distinguish hexapodids from pinnotherids exclusive of asthenognathines. Females of the Pinnotherinae and Pinnotherellinae have extremely wide abdomina whereas those of female hexapodids are much more narrow. Blunt, anteriorly produced projections on the fourth sternites that characterize most genera of the Hexapodidae (clearly illustrated in fig. 38d, Manning and Holthuis, 1981, p. 178) are almost always absent in the Pinnotheridae. The abdomen of members of the Pinnotheridae, especially females, often covers or partially covers the third maxillipeds, a condition not seen in hexapodids.

Distinguishing between members of the Hexapodidae and the Asthenognathinae can be accomplished using several criteria of the dorsal carapace (Table 1). Asthenognathines have a frontoorbital width that occupies the entire frontal margin of the carapace, while in the Hexapodidae, the fronto-orbital width partially occupies that margin. The Asthenognathinae typically have downturned fronts that narrow distally; in the Hexapodidae, the front is not down-turned and often widens distally. The fronto-orbital width to posterior width ratio of the hexapodids ranges from $0.34-0.87$, while in the Asthenognathinae, that ratio is close to 1.0. The posterior width to width ratio of the hexapodids ranges from $0.73-0.93$, while in the asthenognathines, that ratio ranges from $0.64-0.66$. Asthenognathines have larger posterolateral reentrants than do hexapodids. 
Members of the Hexapodidae and some of the Chasmocarcininae share many characters, such as a bilobed front, a rectangular or trapezoidal carapace, a wide posterior margin, and fusion of abdominal somites in males (Table 1). Similarities are especially apparent among Chasmocarcinus, Collinsius, Falconoplax, Orthakrolophos n. gen., and the hexapodids. However, there are several methods that are useful in distinguishing these taxa. In general, the carapace regions of most members of the Chasmocarcininae are better developed than those of the Hexapodidae, and the carapace tends to be more narrow than that of hexapodids. Some genera of the Chasmocarcininae possess small anterolateral spines or lobes and some are widest near the anterior margin of the carapace, immediately distinguishing them from hexapodids. Also, some chasmocarcinines lack fusion in the abdominal somites of males which characterizes all hexapodid males. The fronto-orbital width of chasmocarcinines typically occupies nearly the entire or the entire frontal margin of the carapace, while in the hexapodids, the fronto-orbital width only partially occupies the frontal width. Additionally, the fronto-orbital width to posterior width ratio in the Chasmocarcininae ranges from about 0.77-1.2 and is usually considerably lower in the Hexapodidae, ranging from $0.34-0.87$. The posterior width to width ratio in the Hexapodidae ranges from about $0.73-0.93$, with the exceptions Globihexapus and Spiroplax, while that ratio in the Chasmocarcininae, ranging from $0.41-0.56$, is considerably lower.

Although we recognize the utility of the appendages, genitalia, and other typically "soft" structures of the organisms used by biologists to classify these animals, diagnoses presented here are based upon dorsal carapace characters commonly preserved in fossils. This approach is intended to facilitate paleontological study of these brachyurans and therefore maximize their utility in paleobiogeographic, paleoecological, and evolutionary research.

The first verifiable occurrences of the Hexapodidae in the fossil record are Goniocypoda rajasthanica from the Paleocene of India (Glaessner, 1933), and Palaeopinnixa rocaensis (Feldmann et al., 1995), from the Paleocene of Argentina. Goniocypoda tessieri was described from the Maastrichtian of Senegal (Remy and Tessier, 1954); however, that occurrence has not been verified.

Of the hexapodid genera known solely from the fossil record, Goniocypoda has a primarily Tethyan distribution, having been recovered from Eocene deposits of England, France, Romania, Egypt, Pakistan, and India (Woodward, 1867; Bittner, 1893; Carter, 1898; Glaessner, 1933; Crane, 1981; Crane and Quayle, 1986). The earliest known occurrence of the genus is from the Paleocene of India (Glaessner, 1933), suggesting that the genus evolved in the Tethyan region during the Paleocene and subsequently dispersed throughout that region and became most diversified in Europe. Globihexapus n. gen. appears to be endemic to the Pacific Northwest of North America.

The hexapodid genus Stevea has a trans-Atlantic Ocean distribution; one fossil species, $S$. cesarii Beschin et al., 1994, is known from the Eocene of Italy, and one extant species has been described from the west coast of Mexico (Glassell, 1938; Manning and Holthuis, 1981). The genus appears to have evolved in the Mediterranean region during the Eocene and subsequently dispersed across the Atlantic Ocean to North America, a similar distribution as has been reported for several other decapod taxa (Feldmann et al., 1998; Schweitzer and Feldmann, 2000; Schweitzer and Salva, 2000).

Palaeopinnixa is first known from the Paleocene of Argentina (Feldmann et al., 1995), and subsequently occurs in Eocene rocks of Peru (Woods, 1922) and Washington (Rathbun, 1926; Schweitzer et al., 2000), Oligocene rocks of Panama (Rathbun, 1918a), and Miocene rocks of Trinidad and Spain (Via, 1966; Collins and Morris, 1976). This suggests that the genus evolved in the high southern latitudes as early as the Paleocene and subsequently dispersed to the Pacific Ocean, Caribbean, and northeastern Atlantic Ocean by Miocene time. Dispersal to the Pacific Ocean could have been facilitated either by dispersal around the northern or southern portion of South America and to the North Atlantic via surface currents.

Members of Hexapus are reported from Miocene rocks of Japan (Imaizumi, 1959) and Pakistan (Collins and Morris, 1978) and Pliocene rocks of Indonesia (Morris and Collins, 1991). Recent species have been described from Southern India, Thailand, and Japan (Manning and Holthuis, 1981). This suggests that the genus arose in the Indo-Pacific region as early as the Miocene and has subsequently remained endemic to that area.

Nine hexapodid genera are known only from modern oceans. Of these, three have Indo-Pacific distributions, including the two monospecific genera Lambdophallus, reported from India, and Hexaplax reported from Indonesia, Thailand, Japan, and the Philippines (Manning and Holthuis, 1981). The three species of Paeduma have been described from Thailand (Manning and Holthuis, 1981). One hexapodid genus, Hexapinus, has an Indo-Pacific and Atlantic Ocean distribution. The four known species of Hexapinus have been reported from Japan, Australia, the Persian Gulf, and West Africa (Manning and Holthuis, 1981). Five of the extant hexapodid genera are known only from Africa and each is monospecific; Parahexapus, Thaumastoplax, and Pseudohexapus are known from West Africa, and Spiroplax and Tritoplax have been described from South Africa (Manning and Holthuis, 1981).

All extant hexapodids are known either from the Indo-Pacific region or from Africa, with the exception of Stevea williamsi from Mexico. This is a more restricted distribution than is seen in the fossil record, in which hexapodids are known from localities worldwide. The restricted distribution of this family, as well as the small number of extant species, suggests that it is a highly specialized group that has remained conservative and is adapted to a small number of very specific niches.

\section{Genus GlobiheXAPus new genus}

Type species.-Globihexapus paxillus new species, by monotypy.

Diagnosis.-Carapace wider than long, narrowest anteriorly; carapace regions moderately developed, finely and locally granular; ridges parallel to anterolateral margin composed of peg-like tubercles; orbits directed obliquely toward axis, rimmed with tiny granules; posterolateral reentrants and posterior margin with granular rim; branchial regions strongly inflated.

Etymology.-From the Latin word globus, indicating the rounded nature of the carapace and inflated branchial regions, and the name Hexapus, which is commonly used as a stem for generic names within the family Hexapodidae.

Occurrence.-As for the species.

Discussion.-The new genus is clearly referable to the Hexapodidae based upon its possession of only four pairs of pereiopods. It also exhibits a transversely elongate carapace and ridges parallel to the lateral margins of the carapace, well developed rostrum and orbits, and it achieves its maximum width near the posterior margin of the carapace.

Globihexapus differs from all other hexapodid genera in several respects. The orbits are directed obliquely toward the axis of the animal, which is unique among the Hexapodidae. Additionally, the carapace of Globihexapus is markedly rounded laterally and narrows considerably toward the anterior margin of the carapace, a shape unique among hexapodids. The anterolateral margin of the carapace is ornamented with a ridge composed of small, peglike tubercles, also unique among the hexapodids. The branchial regions of Globihexapus are strongly inflated, whereas in all other 
TABLE 2-Average ratios and ranges of ratios for all genera included in the key. Numbers in parentheses after each generic name represent, in order, the number of species that were measured for each genus, the total number of species in each genus, and the total number of specimens measured. The first number indicates the average for each ratio, and the second set of numbers indicates the range for each set of ratios. F/FOW $=$ frontal width/fronto-orbital width; FOW/W = fronto-orbital width/maximum carapace width; FOW/PW = fronto-orbital width/posterior width; L/W = maximum carapace length/ maximum carapace width; $\mathrm{PW} / \mathrm{W}=$ posterior width/maximum carapace width.

\begin{tabular}{|c|c|c|c|c|c|}
\hline Genus & F/FOW & FOW/W & FOW/PW & $\mathrm{L} / \mathrm{W}$ & $\mathrm{PW} / \mathrm{W}$ \\
\hline Asthenognathus & 0.39 & 0.56 & 1.03 & 0.67 & 0.64 \\
\hline$(2-5-2)$ & $0.36-0.41$ & $0.48-0.63$ & $1.00-1.06$ & $0.65-0.69$ & $0.59-0.69$ \\
\hline Chasmocarcinus & 0.41 & 0.48 & 1.2 & 0.72 & 0.41 \\
\hline$(3-12-3)$ & $0.36-0.42$ & $0.43-0.50$ & $1.1-1.3$ & $0.71-0.73$ & $0.38-0.45$ \\
\hline Collinsius & 0.25 & 0.56 & 1.00 & 0.81 & 0.56 \\
\hline$(1-1-1)$ & N/A & N/A & N/A & N/A & N/A \\
\hline Falconoplax & 0.36 & 0.42 & 0.77 & 0.80 & 0.54 \\
\hline$(2-2-4)$ & N/A & $0.40-0.43$ & $0.70-0.87$ & $0.78-0.81$ & $0.46-0.61$ \\
\hline Globihexapus & 0.44 & 0.34 & 0.62 & 0.65 & 0.59 \\
\hline$(1-1-1)$ & N/A & N/A & N/A & N/A & N/A \\
\hline Goniocypoda & 0.18 & 0.64 & 0.85 & 0.70 & 0.80 \\
\hline$(5-8-5)$ & $0.17-0.21$ & $0.56-0.71$ & $0.77-0.85$ & $0.61-0.78$ & $0.77-0.83$ \\
\hline Hexapinus & 0.52 & 0.41 & 0.57 & 0.63 & 0.73 \\
\hline$(1-4-1)$ & N/A & N/A & N/A & N/A & N/A \\
\hline Hexaplax & 0.37 & 0.61 & 0.76 & 0.74 & 0.81 \\
\hline$(1-1-1)$ & N/A & N/A & N/A & N/A & N/A \\
\hline Hexapus & 0.47 & 0.32 & 0.34 & 0.60 & 0.93 \\
\hline$(1-3-1)$ & N/A & N/A & N/A & N/A & N/A \\
\hline Lambdophallus & 0.56 & 0.39 & 0.87 & 0.83 & 0.87 \\
\hline$(1-1-1)$ & N/A & N/A & N/A & N/A & N/A \\
\hline Orthakrolophos & N/A & 0.55 & 0.93 & 0.70 & 0.54 \\
\hline$(3-3-3)$ & & $0.44-0.62$ & $0.74-1.2$ & $0.66-0.76$ & $0.52-0.59$ \\
\hline Paeduma & 0.56 & 0.46 & 0.76 & 0.46 & 0.81 \\
\hline$(1-3-1)$ & N/A & N/A & N/A & N/A & $\mathrm{N} / \mathrm{A}$ \\
\hline Palaeopinnixa & 0.42 & 0.43 & 0.55 & 0.67 & 0.80 \\
\hline$(6-4-4)$ & $0.34-0.46$ & $0.38-0.39$ & $0.47-0.61$ & $0.64-0.70$ & $0.72-0.85$ \\
\hline Parahexapus & 0.59 & 0.39 & 0.49 & 0.57 & 0.80 \\
\hline$(1-1-1)$ & N/A & N/A & N/A & N/A & N/A \\
\hline Prepaeduma & N/A & N/A & N/A & 0.56 & 0.94 \\
\hline$(1-1-1)$ & & & & N/A & N/A \\
\hline Pseudohexapus & 0.36 & 0.45 & 0.56 & 0.71 & 0.80 \\
\hline$(1-1-1)$ & N/A & N/A & N/A & N/A & N/A \\
\hline Spiroplax & 0.42 & 0.53 & 0.86 & 0.78 & 0.61 \\
\hline$(1-1-1)$ & N/A & N/A & N/A & N/A & N/A \\
\hline Stevea & 0.42 & 0.54 & 0.60 & 0.67 & 0.89 \\
\hline$(2-2-3)$ & $0.38-0.44$ & $0.42-0.60$ & $0.46-0.68$ & $0.63-0.73$ & $0.86-0.91$ \\
\hline Thaumastoplax & 0.50 & 0.34 & 0.40 & 0.58 & 0.86 \\
\hline$(1-1-1)$ & N/A & N/A & N/A & N/A & $0.84-0.87$ \\
\hline Tritodynamia & 0.43 & 0.48 & 0.74 & 0.54 & 0.66 \\
\hline$(3-4-3)$ & $0.39-0.46$ & $0.44-0.56$ & $0.65-0.90$ & $0.48-0.59$ & $0.63-0.69$ \\
\hline Viapinnixa & 0.25 & 0.70 & 0.89 & 0.63 & 0.78 \\
\hline$(1-?-1)$ & N/A & N/A & N/A & N/A & N/A \\
\hline
\end{tabular}

hexapodid genera those regiosns are typically less inflated or flattened. Globihexapus paxillus also differs from typical hexapodids in having a posterior width to maximum width ratio of 0.59 as compared with a more typical ratio of over 0.70 , illustrating the range of variation within the family. Unfortunately, details of the sternum and abdomen are not preserved.

This report of a new genus of the Hexapodidae brings the total number of genera included in the family to fourteen. Globihexapus, Goniocypoda, and Palaeopinnixa are the only genera known exclusively from the fossil record. Stevea Manning and Holthuis and Hexapus de Haan have previously been reported from the fossil record. Globihexapus is a unique form and appears to be endemic to the Pacific Northwest region.

\section{GLOBIHEXAPUS PAXILLUS new species}

\section{Figures 1, 2}

Diagnosis.-Carapace wider than long, narrowed anteriorly; carapace regions moderately developed; carapace regions finely and intermittently granular; ridges parallel to anterolateral margin composed of peg-like tubercles; orbits directed obliquely toward axis, rimmed with tiny granules; posterolateral reentrants and posterior margin with granular rim; branchial regions inflated.

Description.-Carapace wider than long $(\mathrm{L} / \mathrm{W}=>64.5)$, $\max -$ imum width approximately 60 percent the distance posteriorly on carapace; carapace surface finely and locally granular, especially on hepatic and branchial regions; finely punctate on axial regions; carapace regions weakly inflated, except for inflated branchial region; carapace grooves moderately developed. Carapace surface flattened, lateral sides steeply rounded.

Frontal margin about 16.0 percent maximum carapace width. Orbits subrectangular, rimmed with tiny granules, directed forward and axially, outer orbital angle formed by anterolateral corner of carapace, inner orbital angle posterior-most point of orbital rim. Rostrum not well known, medially sulcate, granular, appearing to narrow distally, lateral margins form inner margin of orbits. Fronto-orbital width about 34 percent maximum carapace width.

Anterolateral and lateral margins continuous; ridge developed along edge of anterolateral margin, composed of small peglike granules; anterolateral margin nearly straight; lateral margin convex. Shallow, concave reentrant at posterolateral corner, with granular rim. Posterior margin about 59 percent maximum carapace width, slightly sinuous, with granular rim.

Cervical groove extends from midpoint of anterolateral margin, convex forward laterally, then curves posteriorly in broad, Ushape across axial region, most strongly developed posteriorly, most weakly developed anteriorly.

Protogastric region tumid posteriorly, flattened anteriorly, two broad swellings at base of rostrum. Hepatic region flattened, 

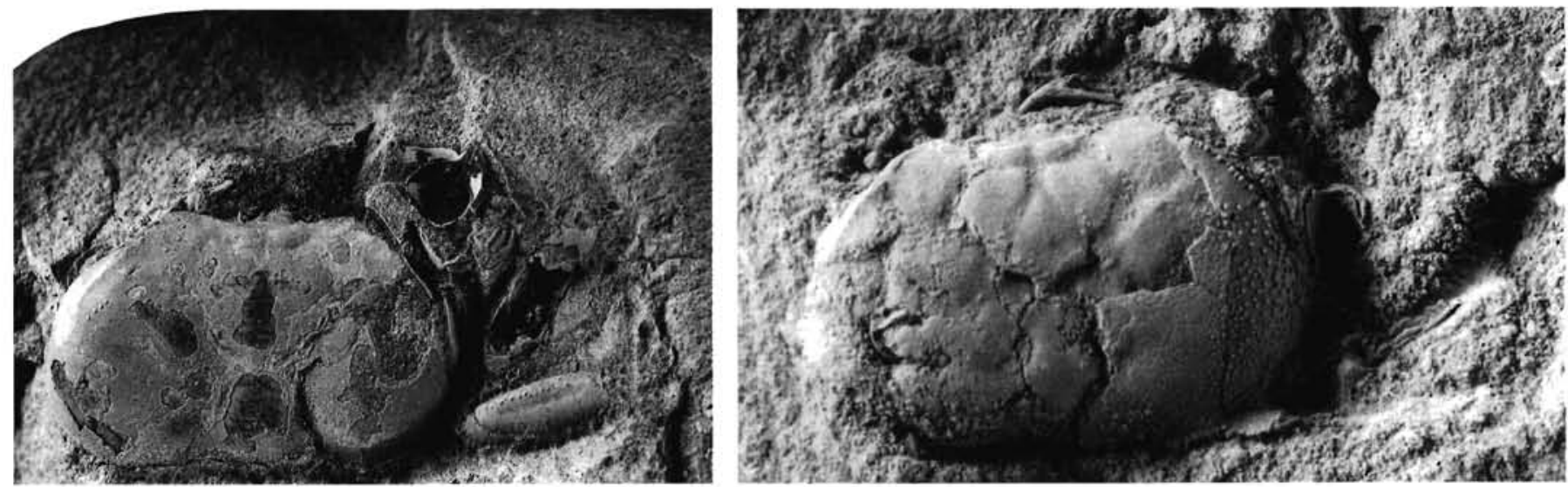

1

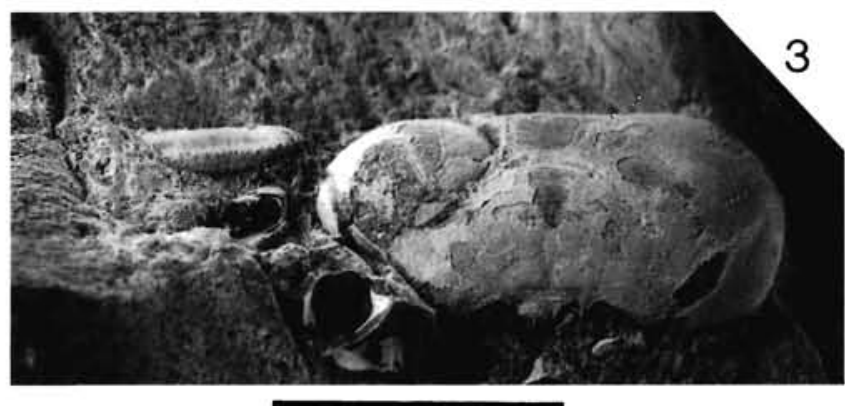

FIGURE 1 -Globihexapus paxillus n. gen. and sp. $I$, Dorsal carapace of holotype, USNM 501841; 2, dorsal view of paratype, USNM 501842; 3 , anterior view of holotype, USNM 501841. Scale bar equal to $1 \mathrm{~cm}$.

sparsely granular. Branchial region large, undifferentiated; tumid posteriorly, with elongate tumid area in anterior-axial corner. Mesogastric region triangular, elongate anteriorly, widened posteriorly, lateral margins concave, posterior margin convex; region bounded by shallow grooves. Urogastric region narrow, constricted centrally, anterior margin concave, posterior margin weakly concave. Cardiac region not well known, moderately tumid, perhaps possessing two small tubercles on either side of axis, bounded by deep grooves.

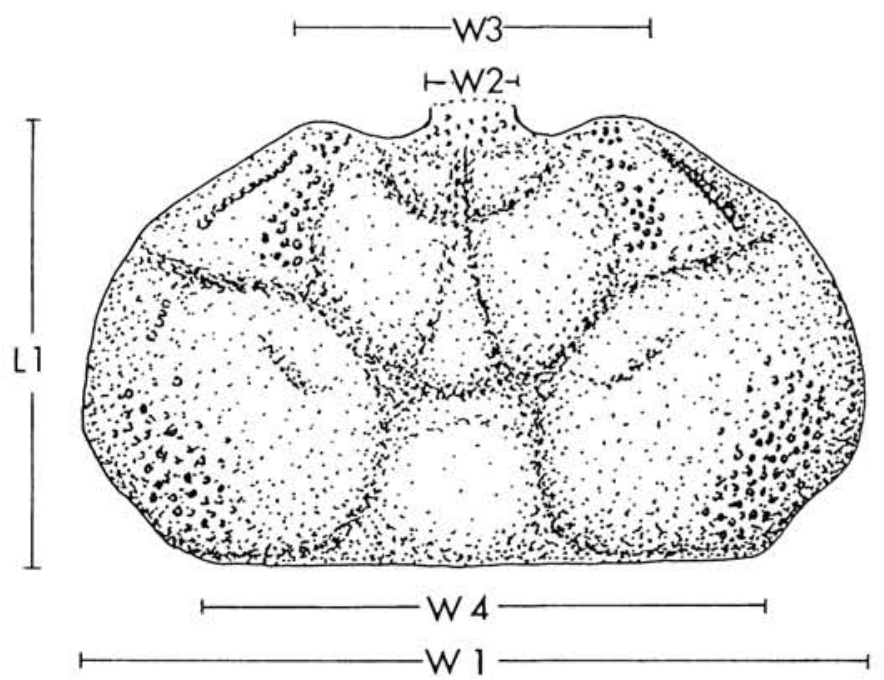

FIGURE 2-Line drawing of Globihexapus paxillus illustrating position and orientation of measurements taken.
Meri of pereiopods 1-4 longer than high, ornamented with granules. Carpus of cheliped short, stout, granular; manus of cheliped granular, finger with denticles.

Etymology.-The species name is derived from the Latin word "paxillus", meaning "peg" or "small stake", referring to the peglike tubercles that define the lateral ridges on the dorsal carapace.

Types.-The holotype, USNM (United States National Museum) 501841, and four paratypes, USNM 501842-501845, are deposited in the United States National Museum of Natural History, Washington, D.C.

Measurements.-See Table 3 for measurements (in $\mathrm{mm}$ ) taken on the dorsal carapace of specimens of Globihexapus paxillus. Position and orientation of dorsal carapace measurements are illustrated in Figure 2.

Occurrence.-All five specimens were collected in concretions at site RB83, which is about $1 \mathrm{~km}$ south of Moolock Brook and about $1 \mathrm{~km}$ north of the Yaquina Head Lighthouse, SE 1/4, Sec. 19, T10S, R11W, 15'series Yaquina Quadrangle, Lincoln Co.,

TABLE 3-Measurements (in $\mathrm{mm}$ ) taken on the dorsal carapace of Globihexapus paxillus $\mathrm{n}$. sp. $\mathrm{L} 1=$ maximum length (including rostrum); $\mathrm{L} 2=$ maximum length measured from base of orbit to posterior margin; $\mathrm{W} 1=$ maximum width; $\mathrm{W} 2$ = fronto-orbital width; $\mathrm{W} 3=$ = frontal width; $\mathrm{W} 4=$ posterior width.

\begin{tabular}{ccccccc}
\hline \hline $\begin{array}{c}\text { USNM } \\
\begin{array}{c}\text { Specimen } \\
\text { number }\end{array}\end{array}$ & L1 & W1 & W2 & W3 & W4 & L2 \\
\hline 501841 & $>10.3$ & 15.6 & 5.7 & 2.5 & 9.2 & 10.0 \\
501842 & $>9.4$ & 14.7 & 4.8 & - & - & 9.4 \\
501844 & $>10.1$ & 15.9 & - & - & - & $>10.1$ \\
\hline
\end{tabular}


Oregon. The rocks at this locality are referred to the Miocene Astoria Formation (Snavely, 1987).

Discussion.-Specimens of Globihexapus paxillus range from possessing densely spaced tubercles on the mesogastric and hepatic regions to having sparse ornamentation on these areas. The axial regions range from being nearly smooth to finely punctate. The ridge parallel to the anterolateral margin varies in composition from small to large peglike tubercles. However, this range in variation may be due to abrasion of the specimen during transport and deposition. The specimen with the least well-developed ornamentation shows clear signs of weathering on the mesogastric region and broken tubercles on the anterolateral ridge.

All five specimens of Globihexapus paxillus appear to be corpses since all possess portions of appendages; this along with the excellent preservation of the delicate peglike tubercles on USNM 501842 suggests that the animals were buried in or near the environment in which they lived. However, USNM 501841 shows clear signs of crushing and fracturing of the right side of the dorsal carapace, and so it is likely that the specimens were at least moderately reworked or crushed.

\section{Genus GonIOCYPODA Woodward, 1867}

Type species.-Goniocypoda edwardsi Woodward, 1867.

Included species.-Goniocypoda collinsi Crane and Quayle, 1986; G. edwardsi, G. elmorensis Crane and Quayle, 1986; G. quaylei Crane, 1981; G. rajasthanica Glaessner and Rao, 1960; G. sindensis Glaessner, 1933; G. sulcata Carter, 1898; G. transsilvanica Bittner, 1893; one subspecies, G. edwardsi audensis Secretan, 1971; and questionably, G. tessieri Remy and Tessier, 1954.

Diagnosis. - Carapace subrectangular; corners rounded, especially anterolateral corner; wider than long, L/W equal to about 0.70 ; carapace regions poorly marked; carapace flattened transversely and vaulted longitudinally. Front narrow, flared, about 18 percent the fronto-orbital width. Fronto-orbital width occupying entire anterior margin of carapace, fronto-orbital width to maximum width ratio about 64 percent; orbital margins sinuous, rimmed, outer edge of orbit intersecting anterolateral corner. Anterolateral margins continuous with posterolateral margins, reentrants at posterolateral corner small, posterior margin nearly straight. Axial regions well developed, sometimes with small nodes. Male abdominal somites fused, either 3-5 or 5-6. Sternite 4 with anterior projections.

Types.-Holotypes, Goniocypoda collinsi SM (Sedgwick Museum, Cambridge, England) C67953; G. edwardsi, 94. Paratypes, G. edwardsi, SM C8487b, C84873 G. elmorensis, In.61802 (In=The Natural History Museum, London, England).

Discussion.-Goniocypoda was originally described by Woodward (1867) for material collected in late Eocene rocks of England. Subsequently at least seven more species or subspecies have been described from several Eocene localities in England, France, Romania, Egypt, Pakistan, and India. Goniocypoda tessieri was reported from Cretaceous rocks of Senegal (Remy and Tessier, 1954), but that occurrence is not verifiable because the description and illustrations of the specimen do not permit conclusive assignment of the species to the genus. The types of this species, which are deposited in the Muséum de Paris, must be examined before further conclusions can be drawn.

Goniocypoda has been described as exhibiting a small outer orbital spine (Glaessner, 1969; Crane and Quayle, 1986). However, species of the genus do not possess a spine; rather, the intersection of the orbital margin with the anterolateral corner forms an acute corner on the carapace that does not extend beyond the margin of the carapace or beyond the orbital margin. Therefore, the diagnosis of the genus is emended to reflect the absence of a spine and instead, the acute intersection of the orbital margin with the anterolateral corner.

The occurrence of species of Goniocypoda in Europe, North Africa, and southern Asia suggests that it had a Tethyan distribution. The oldest confirmed occurrences of the genus are in $\mathrm{Pa}$ leocene to Eocene rocks of India and lower Eocene rocks of France (Glaessner and Rao, 1960; Secretan, 1971), and the genus appears to have arisen and subsequently dispersed throughout the Tethyan region. However, note that confirmation of the genus in Maastrichtian rocks of Senegal would extend the range of the genus into the Cretaceous and would suggest an eastern Tethyan origin for it.

\section{Genus HeXapus de Haan, 1833}

Type species.-Cancer sexpes Fabricius, 1798.

Included Species.-H. sexpes; H. anfractus (Rathbun, 1909); Hexapus decapoda (Morris and Collins, 1991), as Prepaeduma); H. estuarinus Sankarankutty, 1975; H. nakajimai Imaizumi, 1959; H. pinfoldi Collins and Morris, 1978.

Diagnosis. - Carapace wider than long, widening posteriorly, $\mathrm{L} / \mathrm{W}$ about 0.60 , carapace regions poorly developed; branchiocardiac groove weakly developed. Front straight, medially sulcate, not projecting much beyond orbits. Orbits small, well developed, rimmed, directed forward, fronto-orbital width about 32 percent maximum carapace width. Lateral margins with granular, beaded rim; posterolateral re-entrants well developed; posterior margin weakly convex, about 93 percent maximum carapace width. Sternum with blunt, anteriorly produced projections on fourth sternite; sternal grooves deep (clearly illustrated in fig. 33b, Manning and Holthuis, 1981, p. 172). Male abdominal somites 3-5 fused.

Types.-Holotypes, Hexapus pinfoldi, In.61660, H. nakajimai, IGPS79466, Prepaeduma decapoda, In.61994.

Other material examined.-Hexapus sexpes, USNM 120729; H. anfractus, USNM 221731.

Discussion.-Three fossil species of Hexapus are known; however, the holotype and sole specimen of $H$. nakajimai (ISPS79466) is a poorly preserved impression, making it impossible to confirm diagnostic carapace characters. Therefore, the species is provisionally retained in the genus until more and better material is recovered.

Morris and Collins (1991) described the new genus and species Prepaeduma decapoda, which was characterized as possessing five pairs of pereiopods. They placed the new genus within the Hexapodidae on the grounds that it was an ancestral form for Paeduma Rathbun, 1897, that had not yet lost the fifth pair of pereiopods. The holotype (In.61994), deposited in The Natural History Museum, London, England, clearly exhibits seven sternites, diagnostic of the Hexapodidae. The holotype possesses a rectangular carapace that is wider than long and a L/W ratio of about 0.67; small, circular orbits that are directed forward; and a posterior width to width ratio of 0.90 . These characters fall within the diagnostic characters for Hexapus, and so the species Prepaeduma decapoda is herein placed within Hexapus. Prepaeduma decapoda was recovered from Miocene rocks of Borneo, and species of Hexapus are reported from the Miocene to Recent of the Indo-Pacific region (Manning and Holthuis, 1981). It appears that Hexapus evolved and dispersed only within that region. The paratype In.61996, which is figured in Morris and Collins (1991, fig. 57), exhibits eight sternites and five pereiopods and is therefore not a hexapodid. Consequently, In.61996 is placed within Orthakrolophos bittneri (Morris and Collins, 1991, as Palaeograpsus) based upon its rectangular carapace and the configuration of the sternum; it is poorly preserved and probably is an immature female. 

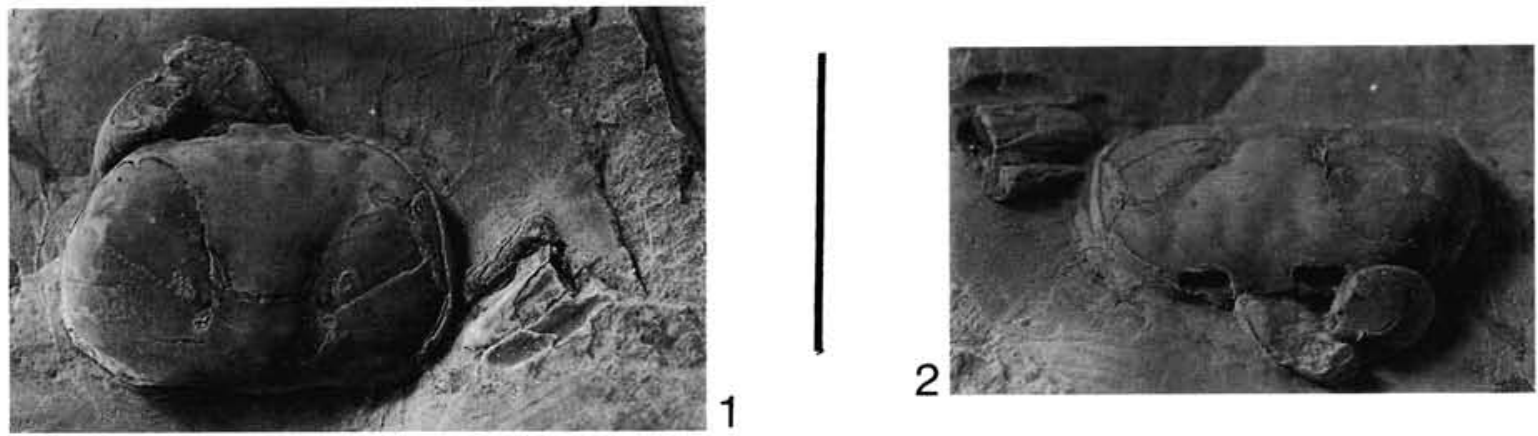

FIGURE 3-Palaeopinnixa rotundus n. sp. 1, Dorsal carapace of holotype, USNM 501836; 2, oblique anterior view of holotype, USNM 501836. Scale bar equal to $1 \mathrm{~cm}$.

\section{Genus PalaeopinniXa Via, 1966}

Type species.-Palaeopinnixa rathbunae Schweitzer, Feldmann, Tucker, and Berglund, 2000, originally Pinnixa eocenica Rathbun, 1926, by original designation; see Schweitzer et al. (2000) for discussion.

Included species.-Palaeopinnixa eocenica (Woods, 1922, as Thaumastoplax); P. intermedia (Collins and Morris, 1976) as Thaumastoplax; P. mytilicola Via, 1966; P. perornata Collins and Morris, 1976; P. prima (Rathbun, 1918a), as Thaumastoplax; $P$. rathbunae Schweitzer, Feldmann, Tucker, and Berglund, 2000; $P$. rocaensis (Feldmann, Casadío, Chirino-Gálvez, and Aguirre-Urreta, 1995), as Thaumastoplax; and P. rotundus $\mathrm{n}$. sp.

Diagnosis. - Carapace wider than long, L/W about 0.67 , carapace widest just anterior to posterolateral re-entrants; carapace rounded rectangular to ovoid, narrowing weakly anteriorly; carapace regions distinct; front widened distally, extending well beyond orbits, axially sulcate, frontal width to fronto-orbital width ratio about 0.42 ; orbits wider than high, with sinuous upper margins, moderately deeply excavated, fronto-orbital width to width ratio about 0.55 ; lateral rim absent or weakly developed; posterolateral re-entrant well developed; posterolateral width to maximum width ratio about 0.80 ; fronto-orbital width to posterior

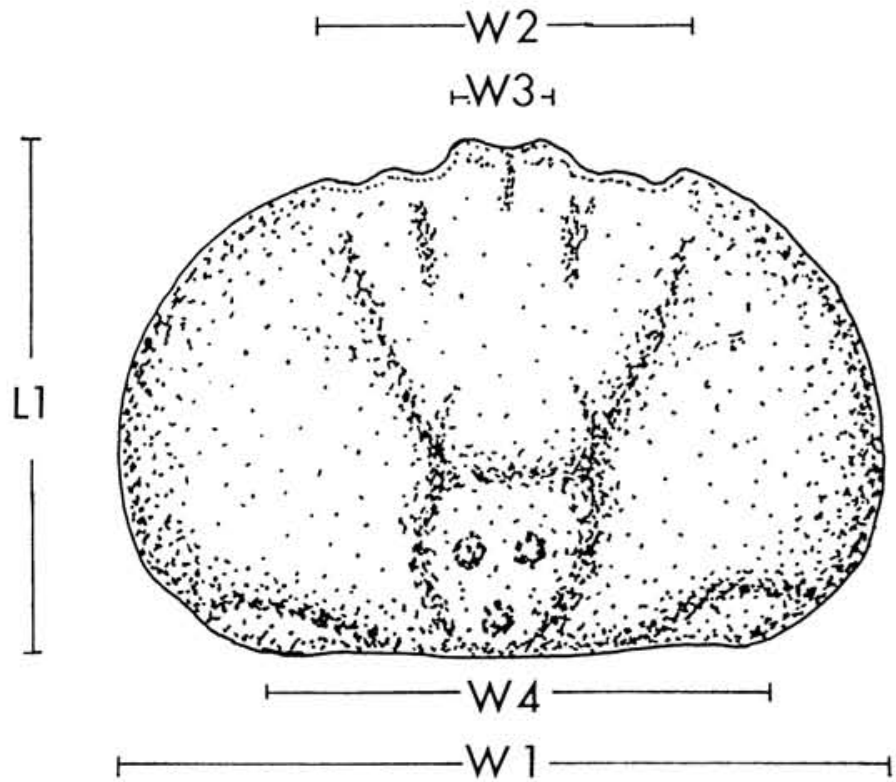

FIGURE 4 -Line drawing of Palaeopinnixa rotundus illustrating position and orientation of measurements taken. width ratio about 0.55 ; abdominal somites $3-5$ fused in males; fourth sternite with anterior projections; third pereiopod longest.

Types examined.-Holotypes, Thaumastoplax intermedia, In.60008, $T$. prima, USNM 324227, $T$. eocenica, SM C1394, $T$. perornata, In.61361, T. rocaensis, GHUNLPam 7006. Paratypes, Thaumastoplax prima, USNM 324228. Type specimen numbers for Palaeopinnixa rotundus n. sp. are given below.

Other material examined.- $P$. rathbunae, CM45870-45900; CM45903, T. rocaensis, GHUNLPam 7007-7009, 7026, 7027.

Discussion.-Schweitzer et al. (2000) elevated Palaeopinnixa Via, 1966 to generic status, moved it from the Pinnotheridae to the Hexapodidae, and referred several fossil taxa previously assigned to Thaumastoplax to it. Collins and Rasmussen (1992) described Pinnixa (Palaeopinnixa) nodosa from the upper Danian of Greenland. That species is not congeneric with Palaeopinnixa rathbunae, the type species of Palaeopinnixa, and therefore a new genus, Viapinnixa, is described here to accommodate that material (see below). Via (1966) considered Pinnixa minuta Rathbun to be a living member of Pinnixa (Palaeopinnixa). Examination of illustrations of that species (Rathbun, 1918b) indicates that it is not in fact a member of Palaeopinnixa based upon its possession of an ovoid carapace, moderately well-defined carapace regions, shallow orbits that are directed anterolaterally, crenulated anterolateral margin, and five pairs of pereiopods. That taxon therefore should remain within Pinnixa.

\section{PALAEOPINNIXA ROTUNDUS new species Figures 3, 4}

Diagnosis.-Carapace rounded-rectangular; carapace regions moderately developed; carapace vaulted longitudinally and flattened transversely; lateral sides steeply rounded; front widest distally, medially sulcate; orbital margin sinuous; anterolateral margin smoothly rounded, continuous with posterolateral margin; branchiocardiac groove deep, well developed.

Description.-Carapace wider than long, L/W about 0.69 , rounded-rectangular in outline; carapace regions finely granular, moderately developed; carapace moderately vaulted longitudinally and flattened horizontally, with steeply rounded lateral sides.

Frontal margin about 17 percent maximum carapace width; front axially sulcate, weakly flared distally. Orbits circular, weakly rimmed, entire, directed forward, with sinuous supraorbital margin; fronto-orbital width about 44 percent maximum carapace width. Anterolateral margin smoothly rounded, continuous with convex posterolateral margin. Posterolateral corner with rounded, concave reentrant. Posterior margin nearly straight, about 78 percent maximum carapace width.

Epigastric region spherical, inflated. Protogastric region moderately inflated; outer margin convex, formed by deep groove; 
TABLE 4-Measurements (in $\mathrm{mm}$ ) taken on the dorsal carapace of Palaeopinnixa rotundus $\mathrm{n}$. $\mathrm{sp}$. $\mathrm{L} 1=$ maximum length (including rostrum); $\mathrm{L} 2=$ maximum length measured from base of orbit to posterior margin; WI $=$ maximum width; $\mathrm{W} 2$ = fronto-orbital width; $\mathrm{W} 3$ = frontal width; $\mathrm{W} 4=$ posterior width.

\begin{tabular}{cclllll}
\hline $\begin{array}{c}\text { USNM } \\
\begin{array}{c}\text { Specimen } \\
\text { number }\end{array}\end{array}$ & L1 & W1 & W2 & W3 & W4 & L2 \\
\hline 501839 & 9.7 & 12.7 & 6 & 2.3 & 9 & 9.1 \\
501840 & 7.7 & 11.3 & 4.7 & 1.8 & 9.9 & 7 \\
501838 & 9.1 & 14.2 & 6 & 2.4 & 10.8 & 8.4 \\
501836 & 8.8 & 12.9 & 5.8 & 2.2 & 10 & 8.5 \\
501837 & $>8.0$ & 13 & 5.6 & 2 & - & $>7.8$ \\
\hline
\end{tabular}

inner margin nearly straight, formed by very shallow groove. Mesogastric region narrow anteriorly and broadened posteriorly; anterior process bounded by very shallow grooves, margins concave; posterior margin convex. Urogastric region narrow, lateral margins concave, bounded laterally by deep grooves. Cardiac region triangular, apex directed posteriorly, two swellings anteriorly and one posteriorly, bounded by moderately deep grooves. Intestinal region flattened, not well developed.

Hepatic region weakly inflated, not well developed. Epibranchial and mesobranchial regions not differentiated, strongly inflated. Metabranchial region flattened.

Manus of major chela about as long as high, surface granular. Meri of pereiopods 2-4 longer than high.

Etymology.-The species name is derived from the Latin word "rotundus", meaning "round," referring to the overall rounded shape of the carapace, which is unique among members of the genus.

Types.-The holotype, USNM 501836, and four paratypes USNM 501837-501840, are deposited in the United States National Museum of Natural History, Washington, D.C.

Measurements.-Measurements (in $\mathrm{mm}$ ) taken on the dorsal carapace of specimens of Palaeopinnixa rotundus are given in Table 4. Position and orientation of measurements made are illustrated in Figure 4.

Occurrence.-Five specimens referred to Palaeopinnixa rotun$d u s$ were collected at RB29 (from the locality register of Ross E. Berglund, Bainbridge Island, WA), located at the north end of Sunset Bay in Sunset Bay State Park, near Cape Arago and west of Charleston, Oregon, in the NW 1/4, sec. 9, T26S, R14W, Charleston Quadrangle, Coos County, Oregon, 7.5' series. Rocks at these exposures have been referred to the late middle to late Eocene Coaledo Formation (Baldwin, 1974; Snavely, 1987).

Discussion.-The new species is placed within Palaeopinnixa based upon possession of a rounded-rectangular carapace, distinct carapace regions, a flared front, orbits with sinuous upper margins, well-developed posterolateral re-entrants, and a posterior width to width ratio of 0.78 . All of these are diagnostic for the genus.

Palaeopinnixa rotundus is most closely related to $P$. rathbunae from the Eocene Hoko River Formation and Eocene rocks questionably referred to the Aldwell Formation but can be distinguished from that species based upon several characteristics. $\mathrm{Pa}$ laeopinnixa rotundus has well-rounded carapace margins and deep branchiocardiac grooves that distinguish it from all other members of the genus. Palaeopinnixa rotundus possesses wider orbits than does P. eocenica Woods. Palaeopinnixa prima has a much more rectangular carapace and narrower orbits than does $P$. rotundus. Palaeopinnixa intermedia has a much more rectangular carapace and more poorly developed regions than does $P$. rotundus. Palaeopinnixa rocaensis has a narrower carapace which is much less vaulted than that of $P$. rotundus. Palaeopinnixa rotundus differs from $P$. mytilicola because has a higher frontoorbital width to width ratio.

The occurrence of the genus Palaeopinnixa in Eocene rocks of the Coaledo Formation in Oregon does not extend the geologic range of the genus but is the first record of the genus in Oregon, USA.

\section{Genus STEvea Manning and Holthuis, 1981}

Type species.-Hexapus williamsi Glassell, 1938.

Included species. - Stevea cesarii Beschin, De Angeli, and Tessier, 1994; S. williamsi (Glassell, 1938), as Hexapus.

Diagnosis. - Carapace rounded-rectangular, narrowed anteriorly, L/W about 0.67; carapace regions not well developed, branchiocardiac groove weakly developed. Front slightly widened distally, medially sulcate. Orbits wide, rimmed, with sinuous margins, fronto-orbital width about 54 percent maximum carapace width. Lateral margins steep; posterolateral re-entrant well developed; posterior width about 90 percent maximum carapace width. Pterygostomial region with stridulating ridges. Sternite 4 with anterior projections. Male abdominal somites 2-6 fused.

Material examined.-Stevea williamsi, USNM 170897.

Discussion.-Stevea is a small genus, with only one known species from the fossil record, S. cesarii from the Eocene of Italy, and one Recent species, $S$. williamsi from the west coast of Mexico. The genus seems to have evolved in the Tethyan region and subsequently dispersed across the Atlantic Ocean and through the Straits of Panama, a dispersal mechanism suggested for numerous other brachyuran taxa (Feldmann et al., 1998; Schweitzer and Salva, 2000; Schweitzer and Feldmann, 2000a, 2000b).

\section{Genus Thaumastoplax Miers, 1881}

\section{1}

Diagnosis.-Carapace wider than long, L/W equal to 0.58 , maximum width just anterior to posterolateral reentrant; carapace rounded-rectangular in shape; carapace regions indistinct; front not projected beyond orbits, medially sulcate, rectangular, frontal width to fronto-orbital width ratio equal to 0.50 ; orbits small, circular, not deeply excavated, fronto-orbital width to total width ratio equal to 0.40 ; lateral rim weakly developed or absent; posterolateral reentrant weakly developed; posterior width to maximum width ratio equal to 0.86 ; fronto-orbital width to posterior width ratio equal to 0.40 ; fourth sternite without anterior projections in females, unknown for males.

Discussion.-Several species have been referred to Thaumastoplax, including the extant $T$. anomalipes and the fossil species $T$. prima, T. eocenica, T. intermedia, and T. rocaensis. Based upon examination of both dorsal and ventral carapace characters, it is clear that the fossil species are not congeneric with $T$. anomalipes and have been assigned to Palaeopinnixa (Schweitzer et al., 2000). These fossil species differ from $T$. anomalipes in several respects. The fossil species now referred to Palaeopinnixa exhibit a rounded-rectangular or ovoid carapace that narrows weakly anteriorly, while in $T$. anomalipes, the carapace is rounded rectangular and does not narrow anteriorly. The carapace regions of the fossil species of Palaeopinnixa are well developed, while the carapace regions of $T$. anomalipes are indistinct. The rostrum of Thaumastoplax anomalipes does not project beyond the orbits, is rectangular, and is axially sulcate while the species of Palaeopinnixa have flared rostra that extend well beyond the orbits. The fossil species of Palaeopinnixa have a sinuous orbital margin and large orbits; the orbits of $T$. anomalipes are small, round and more closely spaced. The posterolateral reentrants of $T$. anomalipes are very poorly developed, while in species of Palaeopinnixa, the posterolateral reentrants are distinct. The point of maximum width 
of the carapace in species of Palaeopinnixa is located just anterior to the posterolateral reentrants of the carapace. In T. anomalipes, the point of maximum width is located at about half the distance posteriorly on the carapace. Species of Palaeopinnixa possess anterior projections on the fourth sternites, in specimens in which that portion of the carapace is known; T. anomalipes lacks such projections. Based upon these numerous important differences, the fossil species were removed from Thaumastoplax and placed within the genus Palaeopinnixa Via (Schweitzer et al., 2000). The removal of these taxa from Thaumastoplax restricts the biogeographic range of the genus to the eastern Atlantic Ocean and its geologic range to the Recent.

\section{Family GonePlaCidAE Macleay 1838}

Subfamily ChaSmOCARCininae Serène, 1964

Discussion.-The Chasmocarcininae, as defined by Serène (1964), includes several recent genera, including Chasmocarcinus, Chasmocarcinops, Hephthopelta, Camatopsis, Scalopidia, and Megaesthesius. The only genus of these to have a fossil record, until now, was Chasmocarcinus. With the referral of Collinsius, Falconoplax, and Orthakrolophos n. gen. to the Chasmocarcininae, the fossil record is much more robust. Serène (1964) provided a suite of diagnostic characters for the subfamily but did not include dorsal carapace characters useful in paleontological work. It is suggested here that fossil members of the Chasmocarcininae may be recognized by possession of a trapezoidal carapace; a bilobed or flared front; orbits with sinuous upper margins; a fronto-orbital width that occupies the entire or nearly the entire frontal margin; well-developed posterolateral reentrants, and a fronto-orbital width to posterior width ratio of about 1.0. Additionally, members of the Chasmocarcininae typically have male abdominal somites 3-5 fused and long, narrow pereiopods.

\section{Genus Chasmocarcinus Rathbun, 1898}

Type species. Chasmocarcinus typicus Rathbun, 1898.

Other species.-Chasmocarcinus chacei Felder and Rabalais, 1986; C. cylindricus Rathbun, 1901; C. latipes Rathbun, 1898; $C$. longipes Garth, 1940; C. mississippiensis Rathbun, 1931; C. obliquus Rathbun, 1898; C. peresi Rodrigues de Costa, 1968; C. rathbuni Bouvier, 1917; C. robertsi Blow and Bailey, 1992; $C$. seymourensis Feldmann and Zinsmeister, 1984.

Diagnosis. - Carapace wider than long, trapezoidal, narrowest anteriorly, $\mathrm{L} / \mathrm{W}$ about 0.75 , widest at position of posterolateral flange. Front bilobate, axially sulcate, narrowing slightly distally, not extending much beyond orbits, front about 0.41 fronto-orbital width and 0.20 maximum carapace width. Orbits rectangular, rimmed, shallow, directed forward, upper margin sinuous; frontoorbital width to width ratio about 0.48 , fronto-orbital width to posterior width ratio about 1.2 ; orbits entirely or nearly entirely occupying straight frontal margin. Anterolateral and posterolateral margins indistinguishable, weak ridge parallel to anterior portion of lateral margin; lateral sides steep; laterally directed posterolateral flange just anterior to posterolateral corner; posterior margin sinuous, rimmed. Carapace regions weakly developed. Sternites with small episternal projections. Genital groove in male covered by supplementary sternal plate. Male abdominal somites 3-5 fused.

Discussion.-The genus Chasmocarcinus is distinguishable from genera of the Hexapodidae based upon several characters. In the Hexapodidae, the dorsal carapace is usually rectangular, while in Chasmocarcinus, the carapace is trapezoidal. The posterior width to width ratio in hexapodids ranges from 0.73-0.93 with only two exceptions, while that of Chasmocarcinus averages 0.41 , a significant difference. The average ratio between the fronto-orbital width and posterior width in hexapodids is 0.63 while that of Chasmocarcinus is 1.2. The fronto-orbital width in Chasmocarcinus occupies the entire or nearly the entire frontal width of the carapace, while in hexapodids, the fronto-orbital width only partially occupies the frontal width. The genital groove of males of Chasmocarcinus is protected by a supplemental plate inserted between the sternites 7 and 8 (Felder and Rabalais, 1986) which is never observed in hexapodids. For all of these reasons, hexapodids are distinguishable from members of Chasmocarcinus.

Blow and Bailey (1992) synonymized Falconoplax with Chasmocarcinus and named a new species, $C$. robertsi, from Miocene rocks of Virginia. Herein, we reinstate Falconoplax as a distinct genus and retain $C$. robertsi within Chasmocarcinus (see below). The fossil record for Chasmocarcinus is sparse. In addition to $C$. robertsi, $C$. seymourensis has been described from Eocene rocks of Antarctica, suggesting that the genus evolved in the high Southern latitudes and subsequently dispersed to subtropical areas of the western Atlantic, Caribbean, and eastern and western Pacific regions (Rathbun, 1918b; Feldmann and Zinsmeister, 1984; Felder and Rabalais, 1986).

\section{Genus Collinsius Karasawa, 1993}

Type species.-Collinsius simplex Karasawa, 1993.

Diagnosis. - Carapace rectangular, wider than long, L/W about 0.80 , widest about two-thirds the distance posteriorly on carapace. Front weakly bilobate, axially notched, not deflexed, weakly flared, extending well beyond orbits; frontal width to fronto-orbital width ratio about 0.25 . Orbits with markedly sinuous upper margin, wide, directed forward, occupying entire frontal margin, fronto-orbital width to width ratio about 0.56 , fronto-orbital width to posterior width ratio about 1.0. Anterolateral and posterolateral margins indistinguishable, convex; posterolateral re-entrants absent; posterior margin sinuous, posterior width to width ratio about 0.56 . Axial regions well-defined, especially urogastric and cardiac. Male abdominal somites 3-5 fused.

Discussion.-The monospecific genus Collinsius was originally placed within the Goneplacidae, "subfamily indeterminable" (Karasawa, 1993, p. 72). Affinities with Falconoplax were noted (Karasawa, 1993). Although the two genera are readily distinguishable as noted by Karasawa (1993), they are herein placed within the same subfamily. Collinsius simplex, the sole species of the genus, is easily distinguished from the Hexapodidae because of its extremely sinuous upper orbital margins and its broad fronto-orbital width that occupies the entire frontal margin of the carapace. In hexapodids, the upper orbital margins are not as sinuous and the fronto-orbital width occupies only a portion of the frontal margin. Further, $C$. simplex is much closer to being equidimensional than are hexapodids, which are typically markedly wider than long. Collinsius simplex lacks posterolateral re-entrants, possession of which is diagnostic for hexapodids. With two exceptions, the posterior width to maximum width ratio of hexapodids ranges from $0.73-0.93$, whereas in $C$. simplex, the ratio is about 0.56. The point of maximum width of Collinsius occurs further anteriorly on the carapace than in hexapodids, in which the maximum width is located just anterior to the posterolateral reentrant. The fronto-orbital width to posterior width ratio in C. simplex is about 1.0 , while in hexapodids, that ratio averages 0.63 . Collinsius is currently only known from the Miocene of Japan.

\section{Genus FalCONOPLAX Van Straelen, 1933}

Type species.-Falconoplax kugleri Van Straelen, 1933. 1976.

Other species.-Falconoplax bicarinella Collins and Morris,

Diagnosis.-Carapace wider than long, L/W about 0.80, trapezoidal, widest just anterior to posterolateral reentrant. Front bilobate, axially sulcate, narrowing slightly distally, not extending beyond orbits; frontal width to fronto-orbital width ratio about 
0.36 , frontal width to maximum width ratio about 0.40 . Orbits with straight upper margins, directed axially, deep point of orbits adjacent to front; fronto-orbital width to maximum width ratio about 0.42 , fronto-orbital width to posterior width ratio about 0.77; fronto-orbital width occupying entire frontal margin. Anterolateral and posterolateral margins indistinguishable; posterolateral reentrants small; posterior margin nearly straight, posterior width to maximum width ratio about 0.54 . Regions moderately well developed; epibranchial ridge directed posteromesially from lateral margin; sometimes with strong transverse protogastric-hepatic ridge and longitudinal branchial ridge; mesogastric, urogastric, and cardiac regions well developed. Male genital groove exposed, wide, developed within sternite 8 .

Discussion.- Van Straelen (1933) erected the genus Falconoplax to accommodate material collected from late Eocene rocks of Venezuela and placed the new genus within the Goneplacidae. Glaessner (1969) subsequently placed the genus within the Dorippidae, subfamily Tymolinae (p. R492). Tavares (1992) convincingly argued that the genus cannot be retained within the Dorippoidae based upon the position of the genital openings, which indicate that Falconoplax is a heterotreme, and further suggested that it was closely related to the Goneplacidae. We concur. Blow and Bailey (1992) synonymized Falconoplax with Chasmocarcinus based upon several superficial similarities. However, there are some key differences between the two genera. Falconoplax has axially directed orbits and well-developed carapace regions and ridges, while species of Chasmocarcinus have forwardly directed orbits and poorly developed carapace regions and ridges. The front on members of Falconoplax is more distinctly bilobate than that of species of Chasmocarcinus. Most importantly, the development of the sternites, specifically in the region of sternites 7 and 8 , is different between the two genera. In species of Chasmocarcinus, the male genital groove is covered by a supplementary plate inserted between sternites 7 and 8. In Falconoplax, the male sternal groove is developed as an open, tubular channel within sternite 8 , resulting in an anterior and posterior portion of sternite 8 . This configuration is apparently unique among the Brachyura (Tavares, 1992). Because of these significant differences, Falconoplax is reinstated and includes F. kugleri and $F$. bicarinella.

The anterior portion of sternite 8 in Falconoplax is shaped much like the interplate of Chasmocarcinus, which suggests that Falconoplax may have been ancestral to Chasmocarcinus. The anterior portion of sternite 8 in Falconoplax may have developed as a covering to protect the genital groove, which in that genus is completely exposed. Chasmocarcinus may represent a descendent taxon in which the plate has developed to completely cover and protect the male genitalia.

Falconoplax is easily distinguishable from genera of the Hexapodidae because Falconoplax has well-developed carapace regions and ridges, axially directed orbits, a fronto-orbital width that occupies the entire frontal margin, carapace ridges, and the unique genital groove in sternite 8 . Falconoplax is known only from the fossil record, from Eocene localities in Venezuela and Barbados, overlapping the range of both Recent and fossil species of Chasmocarcinus.

\section{Genus Orthakrolophos new genus}

Type species.-Palaeograpsus depressus Quayle and Collins, 1981.

Included species.-Orthakrolophos depressus; O. bartonensis (Quayle and Collins, 1981), as Palaeograpsus; and O. bittneri (Morris and Collins, 1991), as Palaeograpsus.

Diagnosis. - Carapace trapezoidal, wider than long, L/W about 0.70 , widest just anterior to posterolateral re-entrants; front weakly flared, not extending beyond orbits, fronto-orbital width to width ratio about 0.55 , fronto-orbital width entirely occupying frontal margin; orbits broad, rimmed, upper margin sinuous; anterolateral and posterolateral margins indistinguishable; posterolateral reentrant large, with beaded rim; posterior margin about 0.54 maximum carapace width, with beaded rim, posterior width to fronto-orbital width ratio about 0.93 . Carapace regions not well developed, axial regions well defined by narrow grooves, cardiac region with transverse ridge; branchial regions with two transverse ridges on level with cardiac ridge and posterolateral reentrant; sometimes with epibranchial transverse ridges.

Etymology.--From the Greek words orthos, meaning straight, and akrolophos, meaning ridge or crest, denoting the straight, transverse ridges of the dorsal carapace diagnostic of the genus.

Material examined.-Holotypes, Palaeograpsus depressus, In.61741, Palaeograpsus bittneri, In.61987. Paratypes, $P$. depressus, In.61739, P. bittneri, In.61990-93.

Discussion.-Several species have been referred to the genus Palaeograpsus since it was erected by Bittner in 1875 . The type species, $P$. inflatus, was assigned to the Grapsidae, a placement with which we concur, based upon the broad front, small orbits placed at the anterolateral corners, anterolateral spines, rectangular shape, carapace that is about as long as wide, and broad, transverse ridges on the protogastric, hepatic, and branchial regions. Palaeograpsus attenuatus Bittner, 1875, has not been examined by the authors and therefore remains in Palaeograpsus.

Subsequently, Lörenthey (1897) described $P$. loczyanus from Eocene rocks of Hungary; Beschin et al. (1996) concurred with placement of that species within Palaeograpsus. Via (1969) suggested that $P$. loczyanus bore some resemblance to Carcinoplax, and Karasawa (personal commun.) also suggested that this species is better referred to the Goneplacidae. We concur, and suggest, therefore, that $P$. loczyanus be removed from Palaeograpsus, possibly allied with members of Carcinoplax.

Quayle and Collins (1981) described two species of Palaeograpsus, $P$. depressus and $P$. bartonensis, from the Eocene of England, and Morris and Collins (1991) named P. bittneri from Miocene rocks of Borneo (J. S. H. Collins, personal commun.). The British and Bornean forms differ in several respects from the type species, $P$. inflatus. The type species is rectangular, possesses anterolateral spines, has an extremely broad front, has the orbits at the anterolateral corner, and has broad ridges on the protogastric, hepatic and branchial regions. In the British and Bornean forms, the carapace is trapezoidal, there are no anterolateral spines, the front is narrow, the orbits are not at the anterolateral corner, and the ridges are narrower and placed on the branchial and cardiac regions and sometimes on the hepatic regions. Because the British and Bornean forms do not conform to the general diagnosis of the Grapsidae, and because they are much different in form from the type species, $P$. inflatus, they are herein removed from the genus and the family and placed within $O r$ thakrolophos $\mathrm{n}$. gen. within the Chasmocarcininae. Karasawa (personal commun.) has also suggested that these taxa may not belong in the genus Palaeograpsus. The new genus is referred to the Chasmocarcininae because it possesses numerous characteristics typical of that subfamily including a trapezoidal carapace, a flared front, orbits with sinuous upper margins, a fronto-orbital width that occupies the entire frontal margin of the carapace, a posterior width to fronto-orbital width ratio near to 1.0 , and welldeveloped posterolateral re-entrants.

Via (1959) described a new species of Palaeograpsus, P. guerini from the Eocene of Spain. That species was reported by both Quayle and Collins (1981) and Morris and Collins (1991) to be quite similar to the British forms; however, the transverse ridges diagnostic of the British and Bornean forms are not apparent on 
the illustrations of $P$. guerini. Therefore, evaluation of that species must await examination of better illustrations or the type material.

Orthakrolophos has been reported from Eocene rocks of Britain and Miocene rocks of Borneo, suggesting that it evolved during the Eocene in the western Tethys and subsequently dispersed via the Tethys eastward to the Indo-Pacific region.

Section Thoracotremata Guinot, 1977

Superfamily PinNOTHEROIDEA de Haan, 1833

Family PinNOTHERIDAE de Haan, 1833 Genus ViaPINNIXA new genus

Type and only species.-Pinnixa (Palaeopinnixa) nodosa Collins and Rasmussen, 1992, by present designation.

Diagnosis. - Carapace wider than long, L/W equal to 0.63 , carapace widest at about midlength of carapace; carapace roundedrectangular in shape; regions distinct, defined by broad shallow grooves; rostrum narrow, flared, extending well beyond orbits, frontal width to fronto-orbital width ratio 0.25 ; orbits wide, sinuous upper margins, fronto-orbital width to maximum width ratio about 0.70 ; lateral margins rounded, unrimmed, with small, blunt anterolateral spine; posterior margin nearly straight, posterior width to maximum width ratio 0.78 , fronto-orbital width to posterior width ratio 0.89 ; posterolateral corner with reentrant; eight sternites visible.

Etymology.-From Pinnixa, a common stem used for members of the Pinnotheridae, and in honor of Reverend Dr. Luis Vía Boada, El Seminari Conciliarde, Barcelona, who made major contributions to our understanding of the fossil Decapoda.

Discussion.-As was previously discussed, material referred to Pinnixa (Palaeopinnixa) nodosa by Collins and Rasmussen (1992) is not congeneric with material assigned to Palaeopinnixa herein and $P$. $(P$.) nodosa is therefore placed within a new genus, Viapinnixa. Viapinnixa nodosa differs from all species referrable to Palaeopinnixa because it has eight exposed sternites instead of seven; this places Viapinnixa within the Pinnotheridae, an entirely different family from Palaeopinnixa.

Viapinnixa nodosa also differs from all species of Palaeopinnixa because the frontal width to fronto-orbital width ratio of $V$. nodosa is much lower, 0.25 , than that of species of Palaeopinnixa in which that ratio averages 0.42 . The fronto-orbital and posterior widths in $V$. nodosa are broader than in species of Palaeopinnixa; in Palaeopinnixa, the fronto-orbital width to maximum width ratio averages 0.43 and the fronto-orbital width to posterior width ratio averages about 0.55 ; those ratios average 0.70 and 0.89 respectively in $V$. nodosa. Additionally, $V$. nodosa has a small, blunt spine on the anterolateral margin, which all species assigned to Palaeopinnixa lack. The carapace regions of $V$. nodos $a$ are better developed and of an overall different shape from those of species of Palaeopinnixa. The lateral margins of $V$. nodosa are much more convex than those of species of Palaeopinnixa. The fact that $V$. nodosa of the Pinnotheridae superficially resembles species of Palaeopinnixa of the Hexapodidae illustrates the difficulty in working with fossil taxa of these groups. It also clearly demonstrates that assignment to family and subfamily in the fossil record is very difficult and must be done primarily by careful generic assignment. Currently, Viapinnixa is known only from Danian rocks of Greenland (Collins and Rasmussen, 1992).

Subfamily AsthenognathinaE Stimpson, 1858

Diagnosis. Carapace trapezoidal, wider than long, average L/ W about 0.69 with range of $0.54-0.79$; lateral margins usually steep, regions not well defined. Front narrowest distally, axially sulcate, strongly deflexed, not extending or slightly extending beyond orbits. Orbits shallow, straight frontal margin entirely occupied by orbits, upper orbital margin sinuous, usually unrimmed; average fronto-orbital width to width ratio about 0.50 , range of $0.37-0.59$. Anterolateral margins and posterolateral margins indistinguishable, rimmed; posterolateral reentrant large; posterior margin nearly straight, posterior width to width ratio ranging from $0.64-0.66$. Branchial regions typically with crest extending posteromesially from midpoint of lateral margin. Sternite 4 typically without anterior projections. Somites $4-6$ of male abdomen typically fused.

Discussion.-The Asthenognathinae is a small pinnotherid subfamily comprised of Asthenognathus Stimpson, 1858; Aphanodactylus Tesch, 1918; Hapalonotus de Man, 1879; Mortensenella Rathbun, 1909; Opisthopus Rathbun, 1893; Tritodynamia Ortmann, 1894; and Voeltzkowia Lenz, 1905 (non Boettger, 1893; non Saussure, 1899). Of these, only Asthenognathus is known from the fossil record.

The Asthenognathinae is one of four subfamilies of the Pinnotheridae, none of which has a robust fossil record, although they are relatively common in modern environments. Most pinnotherids are small, the cuticle is only weakly calcified, and the individuals are commonly commensals, living within the mantle cavity of mollusks or brachiopods, in cnidarians or echinoderms, or residing with polychaete worms or callianassid arthropods in their burrows (Schmitt et al., 1973). Some species are free-living and most spend some part of their lives independent from the host organism.

Because no attempt is made herein to evaluate the systematics of the entire family, the pinnotherid subfamilies other than the Asthenognathinae will not be discussed in detail. Suffice it to say that the trapezoidal carapace shape of the asthenognathines tends to contrast with the elongate, rectangular or ovoid to circular shapes commonly found in the other subfamilies. Shape is, however, of only limited value in identifying pinnotherids because many undergo major changes in shape during their life histories or exhibit strong sexual dimorphism (Devi, 1986).

Another, more distantly related, taxon whose morphology is similar to that of the asthenognathines is the goneplacid genus Chasmocarcinus Rathbun. For example, Chasmocarcinus tends to be more quadrate, the front is generally bilobed, and the carapace regions are less distinct than in Asthenognathus. Additionally, the pereiopods of Chasmocarcinus are longer and more slender than those of the asthenognathines. The ratio of carapace length to width, about 0.75 , is higher than that of the commonly occurring asthenognathines. Finally, Chasmocarcinus spp. lack any indication of a branchial ridge which asthenognathines typically exhibit.

Asthenognathus urretae $\mathrm{n}$. sp. from the Eocene of Argentina marks the earliest known occurrence of the subfamily. Asthenognathus is known from late Oligocene to early Miocene rocks of Washington (Schweitzer and Feldmann, 1999) and Miocene rocks of Japan (Karasawa, 1993). Extant members of the Asthenognathinae are known from the seas of Japan, China, the IndoPacific, France, and the northwest coast of Africa (Monod, 1956; Sakai, 1976; Manning and Holthuis, 1981). It seems reasonable to suggest that the subfamily first appeared in the high southern latitudes and subsequently dispersed to the Pacific realm and the northern Atlantic region.

\section{Genus Asthenognathus Stimpson, 1858}

Type species.-Asthenognathus inaequipes Stimpson, 1858, by original designation.

Included species.-Asthenognathus inaequipes Stimpson, 1858; A. urretae n. sp.; A. atlanticus Monod, 1933; A. cornishorum Schweitzer and Feldmann, 1999; A. globosa (Karasawa, 1990), as Tritodynamia; and A. hexagonum Rathbun, 1909. 

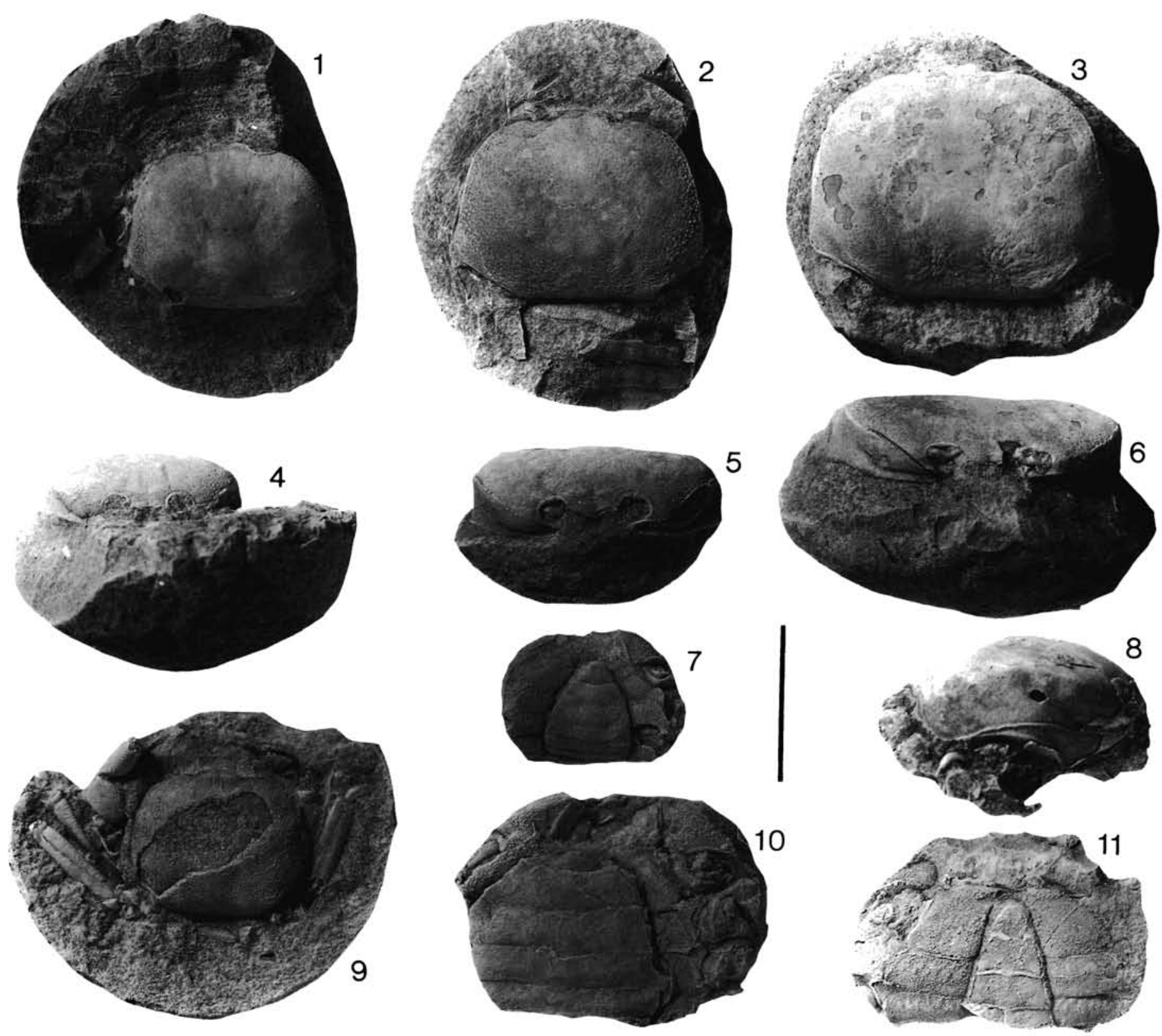

FIGURE 5-Asthenognathus urretae n. sp. 1, Dorsal carapace of holotype, GHUNLPam 16832; 2, dorsal view of paratype, GHUNLPam 16839; 3, dorsal carapace of paratype, GHUNLPam 16845, showing wrinkling of carapace; 4 , frontal view of holotype, GHUNLPam 16832; 5 , frontal view of paratype, GHUNLPam 16836, showing details of rostrum; 6 , frontal view of paratype, GHUNLPam 16845, showing well-preserved eyes and details of the lateral margin; 7, ventral view of immature female paratype, GHUNLPam 16853; 8 , right lateral view of paratype, GHUNLPam, $16837 ; 9$, dorsal view of paratype, GHUNLPam 16835, showing basal elements and meri of pereiopods; 10 , ventral view of mature female paratype, GHUNLPam 16850; 11 , ventral view of male paratype, GHUNLPam 16849. Scale bar equal to $1 \mathrm{~cm}$.

Diagnosis. - Carapace trapezoidal, length to width ratio about 0.66 ; front downturned, sulcate, typically triangular; lateral margins steep and well defined anteriorly, moderately to strongly flared posteriorly; axial regions, particularly cardiac region, well defined; branchial ridge well-defined, narrow, often beaded,extending posteromesially from lateral margins.

Discussion.-Asthenognathus spp. are quite similar to those of Tritodynamia in general appearance; however, species of Asthenognathus tend to be more strongly trapezoidal in outline and somewhat narrower than species of Tritodynamia. The latter group exhibits a more rounded outline and has a length to width ratio of about 0.54 . One of the primary distinguishing features of the two genera, the configuration of the third maxillipeds (Sakai, 1934), is typically not available for study in fossils.

Living species exhibit a disjunct distribution in that they are known from the eastern Atlantic Ocean from France to north Africa, and in the western Pacific and Indian Oceans from Japan to Thailand. The pattern of distribution discernable from the sparse fossil record is one of first occurrence in the Eocene of southern Argentina, presumably linked to the southwestern Atlantic basin, 
and by Oligocene time in the northwest Pacific, in the state of Washington, and finally in Japan during the Miocene.

\section{ASTHENOGNATHUS URRETAE new species Figure 5}

Diagnosis.-Like typical Asthenognathus but with slightly tapering, but not triangular, rostrum; low fronto-orbital width to total width ratio, 0.39 ; high carapace length to width ratio, 0.75 ; and weakly expressed axial regions.

Description.-Carapace typical size for genus; subquadrate to ovoid in outline; weakly vaulted longitudinally; nearly flat transversely; lateral margins well defined, nearly vertical. Carapace often wrinkled as though very thin and delicate.

Front narrow, about 14 percent maximum carapace width measured at posterolateral corners, projected forward and downward with sulcate axis extending farthest forward. Orbits complete above and laterally, partly closed below, open ventromesially; rimmed by narrow, distinct, thickened border which thickens to small protuberance near midlength. Fronto-orbital margin about 39 percent maximum carapace width and narrower than posterior margin. Anterolateral margins diverging posteriorly in smooth curve, defined by narrow, beaded rim extending from lateral corner of orbit to posterolateral corner; rim defines nearly vertical lateral margin along anterolateral margin and curves posteroventrally across posterolateral area to intercept posterolateral corner. Posterolateral corner biconcave, rimmed, with prominent protuberance situated 65 percent of distance from posterolateral corner to posterior corner defining anterior point of insertion of pereiopod 5; defined anteriorly and posteriorly by sharp angle. Posterior margin wide, about 59 percent total width, weakly rimmed.

Dorsal surface smooth to weakly aerolated with mesogastric and cardiac regions poorly defined by shallow grooves; extremely subtle ridge extends from cardiac region anterolaterally to intercept lateral margin at point where marginal rim curves posteroventrally. Surface ornamented by uniformly spaced, tiny setal pits.

Sternum broadening posteriorly, widest at sixth sternite; anterior and posterior margins sinuous; sutures complete and distinct laterally, possibly fused axially. Deep axial furrow on males, broadly depressed on females. Sternites 4-6 with posterolaterally projecting episternal processes defining sinuous margin. Sternites 7 and 8 narrower, reduced in size.

Buccal frame trapezoidal, narrowing slightly anteriorly; MXP3 quadrate, longer than wide, with longitudinal groove extending length of carpus.

Female abdomen not fused, widest at somites 4 and 5, narrowing anteriorly and posteriorly, laterally convex, with subtle axial ridge transversely; immature female abdomen about 54 percent total sternal width measured at level of sixth sternite. Mature female abdomen about 73 percent maximum sternal width. Male abdomen may exhibit fusion of two somites, straight sided, widening to 51 percent maximum sternal width measured at posteriormost end of abdomen.

Five pereiopods evident. First with globose carpus and manus; each slightly longer than high; manus ornamented by one or more subtle longitudinal rows of tiny nodes. Fixed finger slender, slightly curved, with tiny denticles on occlusal surface. Pereiopods $2-$ 4 similar in size, with flattened, elongate meri, 5.9 times as long as wide and 59 percent of maximum carapace width. Pereiopod 5 reduced in size, subdorsal.

Etymology.-The trivial name honors Dr. María Aguirre Urreta, Departamento de Ciencias Geologicas, Universidad de Buenos Aires, who collaborated in field research in Patagonia and has contributed much to our understanding of decapod crustaceans from the area.
Types.-The holotype, GHUNLPam 16832, and 26 paratypes, GHUNLPam 16833-16858, are deposited in the Geological Museum, Universidad Nacional de La Pampa, Santa Rosa, La Pampa, Argentina.

Measurements.-Measurements taken on 20 specimens within the type series are summarized as follows: mean length, $11.3 \mathrm{~mm}$ (range 7.1-15.7); mean width, $14.6 \mathrm{~mm}$; mean frontal width, 2.6 $\mathrm{mm}$; mean fronto-orbital width, $6.5 \mathrm{~mm}$; mean posterior width, $8.7 \mathrm{~mm}$. The following average ratios and their ranges are: Length to width, $0.74(0.61-0.98)$; frontal width to carapace width, 0.16 (0.13-0.21); fronto-orbital width to carapace width, $0.43(0.36$ $0.50)$; posterior width to carapace width, $0.57(0.52-0.63)$; frontoorbital width to posterior width, $0.74(0.63-0.89)$.

Occurrence.-The specimens documenting this species were collected from the Centinela Formation, on the Estancia 25 de Mayo. The type locality, Latitude $50^{\circ} 30.716^{\prime} \mathrm{S}$, Longitude $72^{\circ} 15.303^{\prime} \mathrm{W}$, is about $12 \mathrm{~km}$ south from Calafate, Santa Cruz Province, Argentina. Specimens were collected from numerous other localities in the same stratigraphic unit in exposures extending eastward from the type locality for a distance of about 10 $\mathrm{km}$.

Discussion.-Asthenognathus urretae conforms to the definition of the genus in nearly all regards and can be assigned to that genus with confidence. The configuration of the carapace, front, margins, and carapace regions lie well within the range of forms seen on extant and previously described fossil species. The possession of five pereiopods clearly excludes it from the Hexapodidae and the configuration of the front and the presence of branchial ridges confirm its placement in the Asthenognathinae rather than the Chasmocarcininae.

Two characters serve to distinguish this new species from others within the genus. The ratio of fronto-orbital width to posterior width of Asthenognathus urretae, 0.74, is much lower than that for other representatives of the genus, 1.03. Thus, the fronto-orbital margin is consistently narrower than the posterior margin in the new species but the two dimensions are about equal in other species. In addition, there is a small projection on the posterolateral reentrant of the carapace that marks the point between the fourth and fifth pereiopods that is not seen on other members of the genus.

Individuals of this species are common and occur within tiny concretions in the Centinela Formation. They are associated with a relatively diverse decapod fauna that includes the portunid, Proterocarcinus latus; two cancrids; a geryonid, Chaceon peruvianus; numerous galatheids and other as yet unstudied taxa. Most of the specimens are complete, at least to the extent that the cephalothorax, sternum, and abdomen are all present. Bases of the legs are usually present although the distal elements of the legs may be missing. Thus, it would appear that most of the specimens represent corpses, rather than molted individuals and that there was relatively little transportation of the crabs prior to burial. Because the concretions were collected on the surface of the exposure, it was not possible to determine the orientation of the specimens relative to bedding.

\section{ACKNOWLEDGMENTS}

Specimens from Washington and Oregon, USA, were collected and donated by R. E. and M. Berglund, Bainbridge Island, Washington, and their generosity is appreciated as always. R. B. Manning, late of the United States National Museum, Washington, D.C., generously provided access to the biological collections at that institution, literature, and numerous helpful discussions regarding the Hexapodidae and the Pinnotheridae. H. Karasawa provided access to the decapod collection at the Mizunami Fossil Museum, Mizunami, Japan, and we also thank him for his assistance in evaluating Palaeograpsus. H. Kato provided access to 
the decapod collection at the Natural History Museum and Institute, Chiba, Japan. A. Ross, The Natural History Museum, London, and M. Dorling and R. Long, Sedgwick Museum, Cambridge University, Cambridge, provided access to the collections at their respective institutions. A. Ross and $\mathrm{M}$. Dorling also loaned type material. W. Blow, United States National Museum, Washington, D.C., kindly loaned type material from and provided access to the fossil decapod collection at that institution. A. B. Tucker, Kent State University, Kent, Ohio, provided numerous helpful comments on the fossil material. D. Guinot, Muséum national d'Histoire naturelle, Paris, and J. S. H. Collins, London, provided thoughtful reviews of the manuscript. Material in Argentina was collected by Feldmann with the assistance of Silvio Casadío, Universidad Nacional de La Pampa; María Aguirre Urreta, Universidad de Buenos Aires; and Luis Chirino Gálvez, then of Kent State University, and was funded by National Science Foundation Grant OPP 9417697 and National Geographic Society Grant 5588-95 to Feldmann. Travel to examine Japanese fossil material and material deposited in museums in the United Kingdom was funded by National Geographic Society Grant 6265-98 to Feldmann and Schweitzer.

\section{REFERENCES}

Alcock, A. 1900. The Brachyura Catometopa or Grapsoidea: materials for a Carcinological Fauna of India, No. 6. Journal of the Asiatic Society of Bengal, 69(II:3):279-456.

BALDWIN, E. M. 1974. Eocene Stratigraphy of Southwestern Oregon. Oregon Department of Geology and Mineral Industries Bulletin, 83, $38 \mathrm{p}$.

BALsS, H. 1922. Decapoda Brachyura (Oxyryncha und Brachyryncha) und geographische Übersicht über Crustacea Decapoda: Crustacea VII, p. 70-110, figs. 1-5. In W. Michaelsen, Beiträge zur Kenntnis der Meeresfauna Westafrikas 3.

Beschin, C., A. Busulini, A. De Angeli, and G. Tessier. 1994. I crostacei Eocenici della cava "Boschetto" di nogarole Vicentino. LAVORI-Società Veneziana di Scienze Naturali, 19:159-215.

Beschin, C., A. Busulini, A. De Angeli, G. Tessier, and S. Ungaro. 1996. Crostacei eocenici di "Cava Rossi" presso Monte di Malo (Vicenza-Italia settentrionale). Studi Trentini di Scienze Naturali Acta Geologica, 73:7-34.

BitTNER, A. 1875. Die Brachyuren des Vicentinischen Tertiärgebirges. Denkschriften des Naturhistorischen Staatsmuseums, Wien, 34:63-106.

BITTNER, A. 1893. Decapoden des pannonischen Tertiärs. Sber. Akademie Wissenschaften Wien, 102:10-37, pls. 1-2.

BLOW, W. C., AND R. H. BAILEY. 1992. Chasmocarcinus robertsi, a new crab species from the Miocene of Virginia, with notes on the genus Falconoplax (Crustacea, Decapoda, Goneplacidae). Tulane Studies in Geology and Paleontology, 25(4):175-185.

BOETTGER, O. 1893. Katalog der Batrachier-Sammlung im Museum der Senskenbergischen naturforschenden Gesellschaft in Frankfurt am Main. Druck von Gebrüder Knauer, Frankfurt am Main, 73 p.

BOUVIER, E. L. 1917. Gonéplacidés et pinnothéridés nouveaux recueillis au cours des campagnes américaines du "Hassler" et du "Blake." Bulletin du Muséum National d'Histoire Naturelle, 23:391-398.

CARTER, J. 1898. A contribution to the palaeontology of the decapod Crustacea of England. Quarterly Journal of the Geological Society of London, 54:15-44.

Collins, J. S. H., AND S. F. MoRRIS. 1976. Tertiary and Pleistocene crabs from Barbados and Trinidad. Palaeontology, 19(1):107-131.

Collins, J. S. H., AND S. F. MoRRIS. 1978. New lower Tertiary crabs from Pakistan. Palaeontology, 21:957-981.

Collins, J. S. H, AND H. W. RASMUSSEN. 1992. Upper Cretaceous-Lower Tertiary decapod crustaceans from West Greenland. Grønlands Geologiske Undersøgelse Bulletin 162, $46 \mathrm{p}$.

CRANE, M. D. 1981. Hexapod crabs of the genus Goniocypoda H. Woodward from the upper Eocene of Hampshire. Zoological Journal of the Linnaean Society, 72:1-19.

CRANE, M. D., AND J. Quayle. 1986. Two new hexapod crabs of the genus Goniocypoda Woodward (Crustacea, Decapoda) from the Hampshire Basin. Tertiary Research, 7(4):101-105.

DEVI, S. L. 1986. Some aspects of biology and effect of infestation of
Pinnotheres placunae Hornell and Southwell of Kakinada Bay. Journal of the Marine Biological Association of India, 28:113-123.

Doflein, F. 1904. Brachyura. In Wissenschaftliche Ergebnisse der Deutschen Tiefsee-Expedition auf dem Dampfer "Valdivia" 18981899, 6, 314 p. + Atlas, plate 1-38.

FABRICIUS, J. C. 1798. Supplementum entomologiae systematicae. . C. G. Proft. Hafniae, 572.

FElDER, D. L., AND N. N. RabalaIs. 1986. The genera Chasmocarcinus Rathbun and Speocarcinus Stimpson on the continental shelf of the Gulf of Mexico, with descriptions of two new species (Decapoda: Brachyura: Goneplacidae). Journal of Crustacean Biology, 6:547-575. FeldmanN, R. M., AND W. J. Zinsmeister. 1984. New fossil crabs (Decapoda: Brachyura) from the La Meseta Formation (Eocene) of Antarctica: paleogeographic and biogeographic implications. Journal of $\mathrm{Pa}$ leontology, 58:1046-1061.

Feldmann, R. M., S. Casadío, L. Chirino-Gálvez, and M. AguirreURRETA. 1995. Fossil decapod crustaceans from the Jaguel and Roca Formations (Maastrichtian-Danian) of the Neuquén Basin, Argentina. The Paleontological Society Memoir, 43(Supplement to Journal of Paleontology, Volume 69), 22 p.

Feldmann, R. M., K. L. Bice, C. Schweitzer Hopkins, E. W. Salva, AND K. PICKFORD. 1998. Decapod crustaceans from the Eocene Castle Hayne Limestone, North Carolina: paleoceanographic implications. The Paleontological Society Memoir, 48, 28 p.

GARTH, J. S. 1940. Some new species of brachyuran crabs from Mexico and the Central and South American mainland. Allan Hancock Pacific Expedition, 1:53-95.

GlaESSNER, M. F. 1933. New Tertiary crabs in the collection of the British Museum. Annals and Magazine of Natural History, Ser. 10(12):128 , pls. $1-6$.

GlaessneR, M. F. 1969. Decapoda, p. R399-R651. In R. C. Moore (ed.), Treatise on Invertebrate Paleontology, Pt. R, Arthropoda 4. Geological Society of America and University of Kansas Press, Lawrence.

GlaEsSner, M. F., AND V. R. RaO. 1960. A new species of crab from the early Tertiary Fuller's Earth deposits of Kapurdy, Rajasthan, Western India. Records of the Geological Survey of India, 86:675-682.

Glassell, S. A. 1938. New and obscure decapod Crustacea from the West American coasts. Transactions of the San Diego Society of Natural History, 8(33):411-453, pls. 27-36.

GoRDON, I. 1971. On the thoracic sternum in the subfamily Hexapodinae (Brachyura, Goneplacidae). Crustaceana, 21:106-110, figs. 1-3.

GuINOT, D. 1977. Propositions pour une nouvelle classification des Crustacés Décapodes Brachyoures. Comptes Rendus Académie des Science Paris, D, 285:1049-1052.

HAAN, W. DE. 1833-1850. Crustacea. In P. F. von Siebold, Fauna Japonica sive Descriptio Animalium, quae in Itinere per Japoniam, Jussu et Auspiciis Superiorum, qui Summum in India Batava Imperium Tenent, Suscepto, Annis 1823-1830 Collegit, Notis, Observationibus et Adumbrationibus Illustravit. I-xvii, I-xxxi, 1-243, plates A-J, L-Q, 1-55, circ. tab. 2. Lugduni-Batavorum, Leiden, the Netherlands.

ImAIzumi, R. 1959. A fossil crab, Hexapus nakajimai, n. sp. from Joban Coal Field. Recent Progress of Natural Sciences, 30:25-30, pl. III.

Karasawa, H. 1990. Decapod crustaceans from the Miocene Mizunami Group, Central Japan, Pt. 2, Section Oxyryncha, Cancridea, and Brachyryncha. Bulletin of the Mizunami Fossil Museum, 17:1-33, pls. $1-8$.

Karasawa, H. 1993. Cenozoic decapod crustaceans from Southwest Japan. Bulletin of the Mizunami Fossil Museum, 20:1-92, 24 pls.

LATREILLE, P. A. 1802-1803. Histoire naturelle, générale et particulière, des crustacés et des insectes. Volume 3. F. Dufart, Paris,468.

LENZ, H. 1905. Ostafrikanische Dekapoden und Stomatopoden. Abhandlungen Herausgegeben von der Senckenbergischen Naturforschenden Gesellschaft, 4:341-392, pls. 47-48.

LỐRENTHEY, I. 1897. Adatok Magyarország harmadkorú rák faunájákoz. Mathes Term. Tud. Ért., 15:149-169.

MACLEAY, W. S. 1838. Illustrations of the Annulosa of South Africa. On the brachyurous decapod Crustacea brought from the Cape by Dr. Smith, p. 53-71. In A. Smith (ed.), Illustrations of the Zoology of South Africa, Invertebrate. Smith, Elder, and Company, London.

MAN, J. G. DE. 1879. On some new or imperfectly known podophthalmous Crustacea of the Leiden Museum, Note XIX. Notes from the London Museum, 1:53-73.

MANNing, R. B., AND L. B. Holthuis. 1981. West African brachyuran 
crabs (Crustacea: Decapoda). Smithsonian Contributions to Zoology, 306:1-379.

MiERS, E. J. 1881. On a collection of Crustacea made by Baron Hermann Maltzam at Goree Island, Senegambia. Annals and Magazine of Natural History, series 5, 8:204-220, 259-281, 364-377, pls. 13-16.

MIERS, E. J. 1886. Report on the Brachyura collected by H. M. S. Challenger during the years 1873-1876. Report on the Scientific Results of the Voyage of H. M. S. Challenger during the years 1873-76, Zoology, 17:362 p., plates $1-29$.

MonoD, TH. 1933. Brachyura maroccana, I. Pinnoteridae, avec description d'Asthenognathus atlanticus nov. sp. Bulletin de la Societé des Sciences Naturels du Maroc, XII, no. 4-6, 1932[1933]:142-155, 9 figs.

MoNOD, TH. 1956. Hippidea et Brachyura ouest-africains. Mémoires de l'Institut Français d'Afrique Noire, 45, 674 p.

Morris, S. F., AND J. S. H. Collins. 1991. Neogene crabs from Brunei, Sabah and Sarawak. Bulletin of the British Museum of Natural History (Geology), 47:1-33.

Ortmann, A. E. 1894. Die Decapoden-Krebse des Strasburger Museums. Zoologische Jahrbüchern, Abteilung Systematik, VIII:683-772.

Quayle, W. J., AND J. S. H. Collins. 1981. New Eocene crabs from the Hampshire Basin. Palaeontology, 24:733-758.

RATHBUN, M. J. 1893. Descriptions of new genera and species of crabs from the West coast of North America and the Sandwich Islands. Proceedings of the United States National Museum, 16:223-260.

RATHBUn, M. J. 1897. A revision of the nomenclature of the Brachyura. Proceedings of the Biological Society of Washington, 11:153-167.

Rathbun, M. J. 1898. The Brachyura of the biological expedition to the Florida Keys and the Bahamas in 1893. Bulletin from the Laboratories of Natural History of the State University of Iowa, 4:250-294.

Rathbun, M. J. 1901. The Brachyura and Macrura of Porto Rico. Bulletin of the United States Fish Commission for 1900, 20:1-137.

Rathbun, M. J. 1909. New crabs from the Gulf of Siam. Proceedings of the Biological Society of Washington, 22:107-114.

Rathbun, M. J. 1918a. Contributions to the Geology and Paleontology of the Canal Zone, Panama, and Geologically related areas in Central America and the West Indies. Decapod Crustaceans from the Panama Region. United States National Museum Bulletin, 103, p. 123-184, pls. 54-66.

Rathbun, M. J. 1918b. The Grapsoid Crabs of America. United States National Museum Bulletin, 97, 461 p., 161 plates.

Rathbun, M. J. 1926. The Fossil Stalk-eyed Crustacea of the Pacific Slope of North America. United States National Museum Bulletin, 138, $155 \mathrm{p}$.

Rathbun, M. J. 1931. Two new crabs from the Gulf of Mexico. Proceedings of the Biological Society of Washington, 44:71-72.

REMY, J. M., AND F. TESSIER. 1954. Décapodes nouveaux de la partie Ouest du Sénégal. Bulletin de la Société Géologique de France, 6(4): 185-191, pl. 11.

Rodrigues DA CostA, H. 1968. Crustacea Brachyura récoltés par les draguages de la "Calypso" sur les côtes brésiliennes (1962). Recueil des Travaux de la Station Marine d'Endoume, 43:333-343.

SAKAI, T. 1934. Brachyura from the coast of Kyūshū, Japan. Science Report of the Tokyo Bunrika Daigaku, sect. B, 1(25):281-330.

SAKAI, T. 1976. Crabs of Japan and the Adjacent Seas. Kodansha LTD, Tokyo, Japan.

SANKARANKUTTY, C. 1975. On a new species of Hexapus de Haan (Decapoda, Goneplacidae) from Cochin. Crustaceana, 28(1):1-6, figs. $1,2$.

Saussure, H. L. F. DE. 1899. Orthoptera. Sonderabdruck aus dem Abhandlungen der Senckenbergischen naturforschenden Gesellschaft, 21: 569-664.

SchmitT, W. L., J. C. MCCAIN, AND E. S. Davidson. 1973. Decapoda I, Brachyura I, Fam. Pinnotheridae, p. 1-160. In H.-E. Gruner and L. B. Holthuis (eds.), Crustaceorum Catalogus. W. Junk B. V., Den Haag, The Netherlands.

Schweitzer, C. E., And R. M. Feldmann. 1999. Fossil decapod crustaceans of the late Oligocene to early Miocene Pysht Formation and late Eocene Quimper Sandstone, Olympic Peninsula, Washington. Annals of the Carnegie Museum, 68:215-273.

SChweitzer, C. E., AND R. M. Feldmann. 2000a. Fossils calappids from the Pacific Northwest of and a reevaluation of the Calappidae sensu lato. Journal of Paleontology, 74:230-246.

SChweitzer, C. E., AND R. M. Feldmann. 2000b. New fossil portunids from Washington, USA, and Argentina and a reevaluation of generic and family relationships within the Portunoidea Rafinesque (Decapoda: Brachyura). Journal of Paleontology, 74:636-653.

Schweitzer, C. E., AND E. W. Salva. 2000. First recognition of the Cheiragonidae Ortmann (Decapoda: Brachyura) in the fossil record and comparison of the family to the Atelecyclidae Ortmann (Decapoda: Brachyura). Journal of Crustacean Biology, 20:285-298.

Schweitzer, C. E., R. M. Feldmann, A. B. Tucker, and R. E. BerGLUND. 2000. Eocene decapod crustaceans from Pulali Point, Washington. Annals of the Carnegie Museum, 69:23-67.

SECRETAN, S. 1971. La faune de crustacés décapodes des calcaires à alvéolines Yprésiens des Corbières Septentrionales (Aude), Étude $\mathrm{Pa}$ léontologique, p. 120-142, pls. 8-9. In J.-C. Plaziat and S. Secretan (eds.), La faune de crustacés décapodes des calcaires à alvéolines Yprésiens des Corbières Septentrionales (Aude), Étude Descriptive et Interprétation Paléoécologique des Gisements. Geobios, 4(2):117-142, 3 fig., pl. B, pl. 8-9.

SERÈNE, R. 1964. Redescription du genre Megaesthesius Rathbun et définition des Chasmocarcininae, nouvelle sous-famille des Goneplacidae (Decapoda Brachyura). Crustaceana, 7:175-187.

SNAVELY, P. D., JR. 1987. Tertiary geologic framework, neotectonics, and petroleum potential of the Oregon-Washington continental margin, $\mathrm{p}$. 305-335. In D. W. Scholl, A. Grantz, and J. G. Vedder (eds.), Geology and Resource Potential of the Continental Margin of Western North America and Adjacent Ocean Basins-Beaufort Sea to Baja California. Circum-Pacific Council for Energy and Mineral Resources Earth Science Series, Volume 6 (AAPG Bookstore).

STIMPSON, W. 1858. Crustacea Ocypodoidea: prodromus descriptionis animalium evertebratorum, quae in Expeditione ad Oceanum Pacificum Septentrionalem, a Republica Federata missa, Cadwaladaro Ringgold et Johanne Rodgers Ducibus, observavit et descripsit, Pars V. Proceedings of the Academy of Natural Sciences of Philadelphia, 1858, 93110.

TAvares, M. 1992. Sur la postion systématique du genre Éocène Américain Falconoplax Van Straelen, 1933 (Crustacea, Decapoda, Brachyura). Annales de Paléontologie (Vert.-Invert.), 78:73-81.

TESCH, J. J. 1918. The Decapoda Brachyura of the Siboga Expedition. I. Hymenosomidae, Retroplumidae, Ocypodidae, Grapsidae, and Gecarcinidae. Siboga Expedition, 39:1-148, 6 pls.

Van Straelen, V. 1933. Sur des Crustacés Décapodes cénozoiques du Venezuela. Bulletin du Musée royal d'Histoire naturelle de Belgique, 9:1-14.

VIA, L. 1959. Decápodos fósiles del Eoceno español. Boletin del Instituto Geológico y Minero de Esapaña, Madrid, 70:331-402.

VIA, L. 1966. Pinnixa (Palaeopinnixa) mytilicola nuevo braquiuro fósil, en el miocene marino des Valles (Barcelona). Acta Geologica Hispanica, 1:1-4.

VIA, L. 1969. Crustáceos decápodos del Eoceno español. Pirineos, Jaca, 91-94, 479 p., 39 pls.

Woods, H. 1922. Crustacea from the Eocene Deposits of Peru, p. 114118 , pl. XVII. In T. O. Bosworth (ed.), Geology of the Tertiary and Quaternary Periods in the North-west part of Peru. Macmillan and Co. LTD, London.

WoODWARD, H. 1867. On a new genus of shore-crab, Goniocypoda Edwardsi, from the lower Eocene of Hampshire. Geological Magazine, 4: 529-531.

ACCEPTED 7 NOVEMBER 2000

\section{Appendix A: Key to Genera}

1. Telson with tri-lobate termination . . . . . . . . Tritoplax

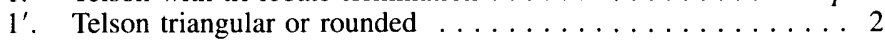

2. Ratio of posterior width to total width less than $0.70 \ldots \ldots$

$2^{\prime}$. Ratio of posterior width to total width greater than or equal to $0.70 \ldots \ldots \ldots \ldots \ldots \ldots \ldots \ldots \ldots \ldots \ldots \ldots \ldots \ldots \ldots \ldots \ldots$

3. Orbits directed anteromesially, fronto-orbital width to width ratio less than $0.35 \ldots \ldots \ldots \ldots$. . . . . . . . . . . . . . .

$3^{\prime}$. Orbits directed anteriorly, fronto-orbital width to width ratio greater than or equal to $0.35 \ldots \ldots \ldots \ldots \ldots \ldots$

4. Carapace with well-developed ridges $\ldots \ldots \ldots \ldots \ldots \ldots \ldots$

4 '. Carapace without well-developed ridges $\ldots \ldots \ldots \ldots$

5. Carapace with posteromesially directed epibranchial ridge and sometimes with longitudinal branchial ridge ...... Falconoplax 
5'. Carapace with transverse branchial and cardiac ridges ... ........................ Orthakrolophos

6. Rostrum small, triangular ............ Asthenognathus

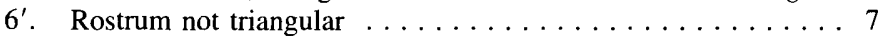

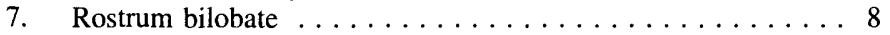

7'. Rostrum poorly developed, widened distally . . . . . . . . 9

8. Frontal to fronto-orbital width less than 0.30 ; rostrum widened distally; upper orbital margin sinusoidal . . . . . . . Collinsius

$8^{\prime}$. Frontal to fronto-orbital width ratio greater than or equal to 0.30 ; rostrum narrowed distally; upper orbital margin weakly sinuous $\ldots \ldots \ldots \ldots \ldots \ldots$. . . . . . . . . . . . . . . .

9. Carapace not much wider than long, rostrum widened distally $\ldots \ldots \ldots \ldots \ldots \ldots \ldots \ldots$. . . . . . . . . . . . . . . . .

$9^{\prime}$. Carapace much wider than long, rostrum not extending well be-

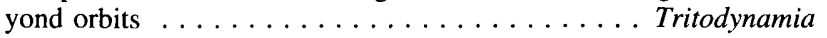

10. Frontal width to fronto-orbital width ratio less than $0.30 \ldots 11$

$10^{\prime}$. Frontal width to fronto-orbital width ratio greater than or equal

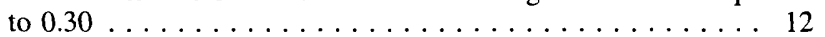

11. Carapace outline rectangular; orbits elongate, wider than high $\ldots \ldots \ldots \ldots \ldots \ldots \ldots$ Goniocypoda

11'. Carapace outline rounded; orbits moderately wide; orbits about as wide as high $\ldots \ldots \ldots \ldots \ldots \ldots$ Viapinnixa

12. Fronto-orbital width to posterior width ratio greater than 0.70

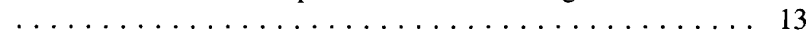

$12^{\prime}$. Fronto-orbital width to posterior width ratio less than or equal

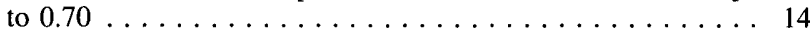

13. Upper orbital margin extremely sinuous, orbit with small sharp medial spine; rostrum with deeply concave lateral margins

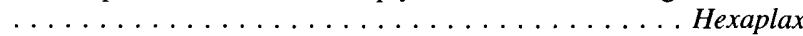

13'. Orbits small, circular; rostrum with straight or weakly convex lateral margins 15
14. Carapace with lateral rim; pereiopods short; cardiac region poorly defined; abdominal somites three/four and five/six fused in males . . . . . . . . . . . . . . . . . . Paeduma

$14^{\prime}$. Carapace without lateral rim; pereiopods long; cardiac region well defined; abdominal somites three-five fused in males

$\ldots \ldots \ldots \ldots \ldots \ldots$ Lambdophallus

15. Posterolateral corner not a marked reentrant . . . . . . . 16

15'. Posterolateral corner a well-developed reentrant . . . . . . 18

16. Fronto-orbital width to width ratio greater than 0.55 ; posterolateral and posterior margins with beaded rim ...... Hexapinus

16 '. Fronto-orbital width to width ratio less than or equal to 0.55 ; posterolateral and posterior margins with smooth rim or unrimmed ..................... 17

17. Rostrum not projected beyond orbits; orbits shallow, small; lateral and posterior margins rimmed ............. $\ldots \ldots \ldots \ldots$ Thaumastoplax sensu stricto.

17'. Rostrum broad, flared; orbits deepest at base of rostrum, deeply excavated; rim on posterior margin indistinct or absent ....

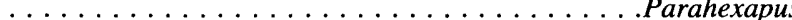

18. Carapace trapezoidal; posterior width to maximum width ratio greater than $0.85 \ldots \ldots \ldots \ldots \ldots$. . . . . . . . . 19

$18^{\prime}$. Carapace ovoid or rectangular; posterior width to maximum width ratio less than or equal to $0.85 \ldots \ldots \ldots \ldots$

19. Orbits shallow; front narrowed distally, sulcate; fronto-orbital width to width ratio less than $0.45 \ldots \ldots \ldots \ldots$.........

$19^{\prime}$. Orbits deep; rostrum widened distally, not markedly sulcate; fronto-orbital width to width ratio greater than or equal to 0.45

20. Carapace ovoid to subrectangular; rostrum well-developed, widened distally; orbits moderately deeply recessed; subtle anterolaterally directed branchial ridge . ......... Palaeopinnixa

$20^{\prime}$. Carapace rectangular; regions indistinct; rostrum not prominent; orbits very shallow; branchial ridge absent . . . . . . . . 